\title{
Article \\ Clinically Relevant Prenatal Ultrasound Diagnosis of Umbilical Cord Pathology
}

\author{
Roxana Elena Bohîlțea ${ }^{1,2, *} \mathbb{0}$, Vlad Dima ${ }^{2, *}$, Ioniță Ducu ${ }^{3}$, Ana Maria Iordache ${ }^{4, *}$, Bianca Margareta Mihai ${ }^{2}(\mathbb{D}$, \\ Octavian Munteanu $^{5}$, Corina Grigoriu ${ }^{1,3, *}$, Alina Veduță ${ }^{2}$, Dimitrie Pelinescu-Onciul ${ }^{1}$ and Radu Vlădăreanu ${ }^{1} \mathbb{C}$
}

1 Department of Obstetrics and Gynecology, "Carol Davila" University of Medicine and Pharmacy Bucharest, 37 Dionisie Lupu, 020021 Bucharest, Romania; dimitriepelinescu@yahoo.com (D.P.-O.); vladareanu@gmail.com (R.V.)

2 Department of Obstetrics, Gynecology and Neonatology, Filantropia Hospital, 11-13 Ion Mihalache Blv., Sector 1, 011171 Bucharest, Romania; bmmihai@gmail.com (B.M.M.); alina.veduta@gmail.com (A.V.)

3 Department of Obstetrics and Gynecology, University Emergency Hospital, 169 Splaiul Independentei Bld., Sector 5, 050098 Bucharest, Romania; ionitaducu@gmail.com

4 Optospintronics Department, National Institute for Research and Development in Optoelectronics-INOE 2000, 409 Atomistilor, 077125 Magurele, Romania

5 Department of Anatomy, "Carol Davila" University of Medicine and Pharmacy Bucharest, 37 Dionisie Lupu, 020021 Bucharest, Romania; octav_munteanu@yahoo.com

* Correspondence: r.bohiltea@yahoo.com (R.E.B.); dima.vlad@yahoo.com (V.D.); ana.iordache@inoe.ro (A.M.I.); corigri@gmail.com (C.G.)

check for

updates

Citation: Bohîlțea, R.E.; Dima, V.;

Ducu, I.; Iordache, A.M.; Mihai, B.M.; Munteanu, O.; Grigoriu, C.; Veduță,

A.; Pelinescu-Onciul, D.; Vlădăreanu,

R. Clinically Relevant Prenatal

Ultrasound Diagnosis of Umbilical

Cord Pathology. Diagnostics 2022, 12,

236. https://doi.org/10.3390/

diagnostics12020236

Academic Editor: Po-Hsiang Tsui

Received: 10 December 2021

Accepted: 17 January 2022

Published: 19 January 2022

Publisher's Note: MDPI stays neutral with regard to jurisdictional claims in published maps and institutional affiliations.

Copyright: (C) 2022 by the authors. Licensee MDPI, Basel, Switzerland. This article is an open access article distributed under the terms and conditions of the Creative Commons Attribution (CC BY) license (https:/ / creativecommons.org/licenses/by/ $4.0 /)$.

\begin{abstract}
Umbilical cord abnormalities are not rare, and are often associated with structural or chromosomal abnormalities, fetal intrauterine growth restriction, and poor pregnancy outcomes; the latter can be a result of prematurity, placentation deficiency or, implicitly, an increased index of cesarean delivery due to the presence of fetal distress, higher admission to neonatal intensive care, and increased prenatal mortality rates. Even if the incidence of velamentous insertion, vasa praevia and umbilical knots is low, these pathologies increase the fetal morbidity and mortality prenatally and intrapartum. There is a vast heterogeneity among societies' guidelines regarding the umbilical cord examination. We consider the mandatory introduction of placental cord insertion examination in the first and second trimester to practice guidelines for fetal ultrasound scans. Moreover, during the mid-trimester scan, we recommend a transvaginal ultrasound and color Doppler assessment of the internal cervical os for low-lying placentas, marginal or velamentous cord insertion, and the evaluation of umbilical cord entanglement between the insertion sites whenever it is incidentally found. Based on the pathological description and the neonatal outcome reported for each entity, we conclude our descriptive review by establishing a new, clinically relevant classification of these umbilical cord anomalies.
\end{abstract}

Keywords: umbilical cord; prenatal diagnosis; ultrasound; 3D imaging; color Doppler; vasa praevia; velamentous cord insertion; umbilical knot; second trimester screening

\section{Introduction}

During embryogenesis, the four folds that emerge on the surface of the embryonic disc in the fourth embryonic week converge centrally in the umbilical area. The primitive umbilical ring is an oval reflection line between the amnion and embryonic ectoderm, which in the 5th week of the embryonic stage, passes the yolk duct and allantois together with the yolk vessels. The embryonic allantoid arteries form the umbilical arteries, and from the left allantoid vein, the umbilical vein is formed. The right umbilical vein that usually degenerates may persist as the single umbilical vein or the fourth vessel of the cord. The connection pedicle that consists of the allantois and umbilical vessels (two arteries and a vein), along with the yolk pedicle, passes through the canal that connects the intraembryonic and the extraembryonic cavities. Subsequently, being covered by 
the amnion, the pedicles form the primitive umbilical cord [1]. The rapid growth of the intestine and liver in the 6th week of embryologic development causes a temporary inadequacy of the abdominal cavity for its contents; as a repercussion, there is an intestinal protrusion in the extraembryonic residual coelom, at the base of the umbilical cord. At the end of the first trimester, the yolk sac located in the chorionic cavity degenerates; thus, physiological herniated intestinal loops resolve after 12 weeks of gestation [2,3]. Subsequently, the umbilical cord vessels remain just surrounded by Wharton's jelly, a mucoid matrix of mesodermal origin. Umbilical arteries present a helical disposition around the vein, forming tortuosities and false nodes.

Umbilical cord anomalies (UCA) are not rare and are often associated with structural or chromosomal abnormalities, fetal intrauterine growth restriction, and poor pregnancy outcomes due to prematurity and placentation deficiency. The NICHD Stillbirth Collaborative Research Network Group reported in 2020 that, from 496 stillbirths wherein cause of death was analyzed and documented using the INCODE (Initial Causes of Fetal Death) classification system, $19 \%$ of deaths were due to umbilical cord abnormalities: a total of $27 \%$ by umbilical cord knots, torsions or stricture; $29 \%$ by nuchal, shoulder or body umbilical cord entanglement; and $5 \%$ were complicated by umbilical cord prolapse [4].

The International Society of Ultrasound in Obstetrics and Gynecology (ISUOG) practice guidelines do not recommend screening for umbilical cord abnormalities. According to its 2013 Practice Guidelines for first-trimester fetal ultrasound scans, the numbers of cord vessels, fetal insertion of the umbilical cord, and the presence of cord cysts should be documented [5]. Imaging the umbilical cord during second trimester prenatal ultrasound examination is optional and limited to determining the number of vessels in the cord and assessment of the fetal insertion site; the study of placental insertion is proposed only for multiple gestations, even if the association of this pathology with pregnancy complications is recognized [6]. ISUOG Practice Guidelines: ultrasound assessment of fetal biometry and growth, from 2019 [7], mentions that future areas of research should include functional imaging of the placenta, which could improve perinatal outcomes. In the last two years, the guidelines have been updated to include Doppler ultrasonography in feto-placental circulation [8,9] and the role of ultrasound in congenital infection [10]; these guidelines stipulate the need for placental cord insertion in preparation for ultrasound-guided invasive procedures [11].

The American Institute of Ultrasound in Medicine (AIUM) guidelines for obstetric ultrasound examination sustain the necessity of imaging the umbilical cord to establish the number of vessels, and the fetal and placental insertion sites, for the standard secondand third-trimester ultrasound examination [12]. The Australasian Society for Ultrasound in Medicine recommends a placental cord insertion evaluation, specifying the variety of marginal and velamentous anomalies; the guideline suggests the benefit of transvaginal color or power Doppler scans with the intent of ruling out vasa praevia [13]. The American College of Radiology (ACR) and the American College of Obstetricians and Gynecologists (ACOG) do not recommend routine evaluation of the placental insertion of the cord, but recommend, when possible, imaging the umbilical cord and the number of vessels [14]. The Society of Obstetricians and Gynaecologists of Canada recommends placental cord insertion evaluation only in cases of low-lying placenta, also advising for transvaginal evaluation of the internal cervical os in cases of placenta praevia, low or velamentous insertion of the cord, vaginal bleeding, bilobed, or succenturiate placenta [15]. The Royal College of Obstetricians and Gynecologists considers that there are insufficient arguments for general population second trimester screening for vasa praevia, even though a transvaginal ultrasound scan presents elevated accuracy, as well as a decreased false positive rate [16]. However, all other pathologies of the umbilical cord (Table 1) are only considered as incidental findings and are not specifically screened for. The evaluation of the free cord loops that could reveal true knots, position, structure and helical pattern anomalies, is not stipulated in any guide.

Both normal anatomy and malformations can be depicted by conventional 2D imaging, but color Doppler should be routinely used for umbilical cord assessment, especially in 
the second half of pregnancy; the benefit of 3D imaging techniques in the diagnosis of umbilical cord knot is indisputable, and enhanced by the HD-flow mode; however, the key to diagnosis is searching for the anomaly [17]. Among the advantages of 3D imaging in the assessment of fetal abnormalities, the most important one refers to the availability of several display modes, which allow the demonstration of even subtle fetal defects from an optimal angle [18]. Compared to 2D ultrasonography, 3D imaging can assess up to $60.8 \%$ of the antenatal defects, proving to be a useful tool in appreciating the severity of a fetal defect [19]. This is especially important when counseling the parents, since virtual examination can help them "see" the severity of a malformation, or the absence of any fetal abnormality $[18,20]$.

The two arteries and the vein composing the umbilical cord should be assessed in both the transverse and longitudinal planes, always associating the color Doppler ultrasound image of the paravesical umbilical vessels in the axial view of the fetal pelvis, in order to exclude single umbilical artery variants. Transvaginal ultrasound is recommended for high-risk pregnancies with placentation anomalies where vasa praevia is suspected $[13,21]$. Sonographically, the umbilical cord can be visualized starting from eight weeks of gestation. From the 10th week of gestation it is possible to determine the number of vessels trough their visualization in the paravesical section using the color Doppler technique. Combined use of transabdominal and transvaginal ultrasound permits a better diagnosis of the placental type, situation, and cord insertion.

Extended analysis of the umbilical cord insertions and tract might offer the advantage of identifying and preventing adverse perinatal outcomes associated with certain umbilical cord abnormalities.

\section{Ultrasonographic Aspects of Pathological Classification of UCA}

In Table 1, we present a summary of the general classification of UCA, indicating the risk factors, incidence, associated pathology and the outcome.

\subsection{Velamentous Cord Insertion}

The velamentous insertion of the umbilical cord (Figure 1) characterized by the divergence of the umbilical vessels as they traverse the amnion and the chorion before reaching the placenta, associates important obstetrical complications; the diagnosis by ultrasonography as early as possible is important for the guidance of the subsequent management. 
Table 1. General classification of UCA.

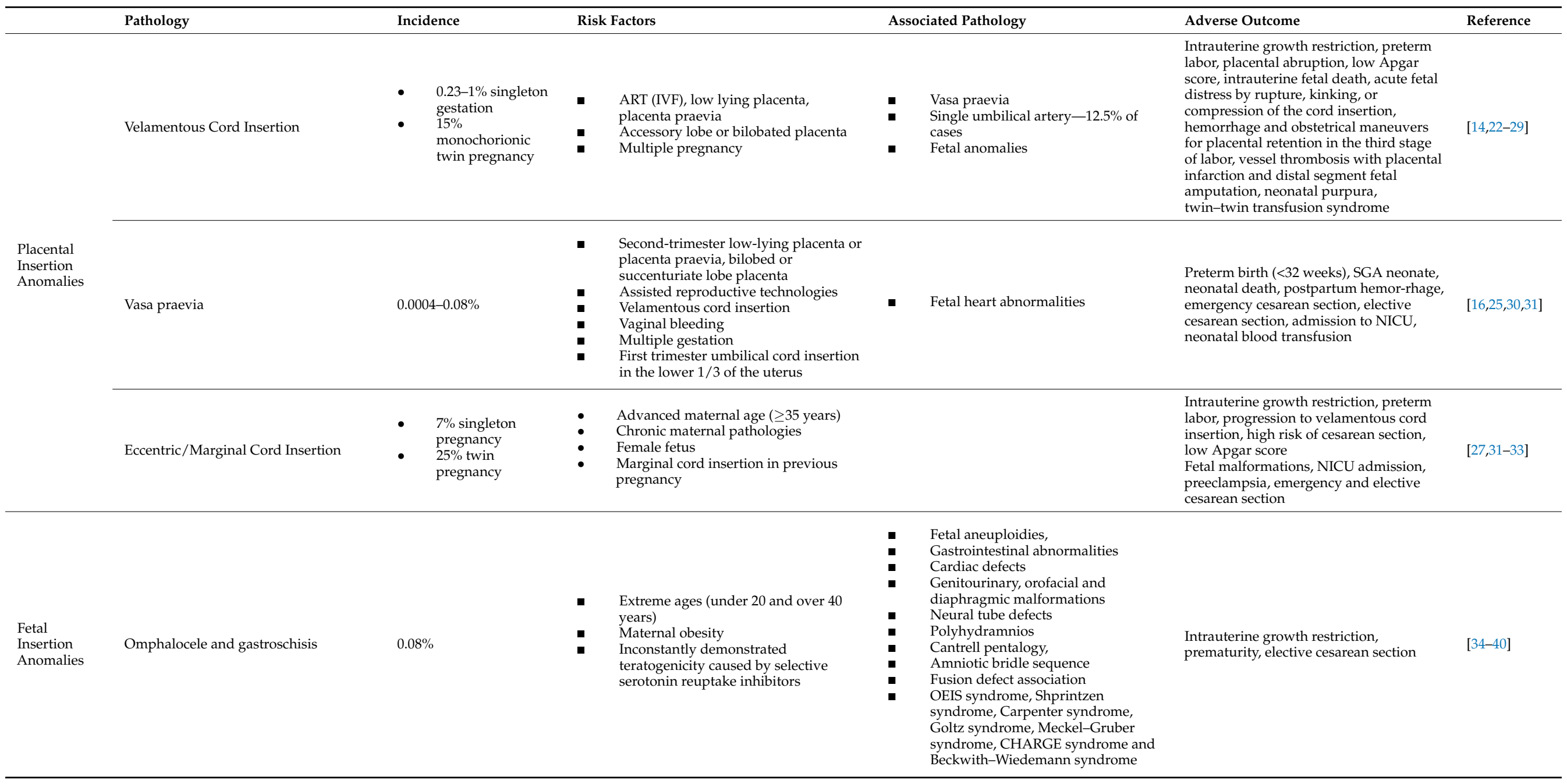


Table 1. Cont.

\begin{tabular}{|c|c|c|c|c|c|c|c|}
\hline & Pathology & & Incidence & Risk Factors & Associated Pathology & Adverse Outcome & Reference \\
\hline \multirow{5}{*}{$\begin{array}{l}\text { Positional } \\
\text { anomalies } \\
\text { Cord } \\
\text { anomalies }\end{array}$} & & Nuchal Cord & $\begin{array}{l}\text { Between } 35 \% \text { and } 0.6 \% \\
\text { (>3 loops) }\end{array}$ & $\begin{array}{ll}\text { - } & \text { Excessive fetal movement } \\
\text { Excessive long umbilical cord } \\
\text { - } \quad \text { Monoamniotic twins } \\
\text { Number of loops increases with } \\
\text { gestational age } \\
\text { Male fetuses }\end{array}$ & Cord knot & $\begin{array}{l}\text { Intrauterine growth restriction, acute } \\
\text { fetal distress, perinatal death, stillbirth, } \\
\text { operative vaginal delivery, emergency } \\
\text { cesarean delivery, need of oxygen } \\
\text { supplementation at delivery }\end{array}$ & [41-47] \\
\hline & & Cord Knot & $0.3-1.3 \%$ & $\begin{array}{ll}\text { - } & \text { Advanced maternal age } \\
\text { Multiparity } \\
\text { Obesity } \\
\text { - } & \text { Previous spontaneous abortion } \\
\text { - } & \text { Gestationyerertension } \\
\text { - } & \text { diabetes }\end{array}$ & Long umbilical cord length & $\begin{array}{l}\text { Prematurity, low Apgar score, NICU } \\
\text { admission, emergency cesarean delivery, } \\
\text { elective cesarean delivery, antepartum } \\
\text { and intrapartum fetal death (likelihood } \\
\text { of stillbirth is more than } 4 \text {-fold higher) }\end{array}$ & {$[17,48,49]$} \\
\hline & & Cord Strictures & rare & Twin pregnancy & $\begin{array}{l}\text { - Umbilical cord overcoiling } \\
\text { - Long umbilical cord length }\end{array}$ & $\begin{array}{l}\text { Intrauterine growth restriction, } \\
\text { Intrauterine fetal death }\end{array}$ & [50] \\
\hline & \multirow{2}{*}{$\begin{array}{l}\text { Structural } \\
\text { anomalies }\end{array}$} & $\begin{array}{l}\text { Single Umbilical } \\
\text { Artery }\end{array}$ & $0.55-5.9 \%$ & $\begin{array}{ll}\text { - } & \text { Extremes of maternal age } \\
\text { Diabetes } \\
\text { Smoking } \\
\text { - } \quad \text { Typertension } \\
\text { Twin pregnancy }\end{array}$ & $\begin{array}{ll}\text { - } & \text { Genitourinary malformations } \\
\text { - } & \text { Caudal regression syndrome } \\
\text { - } & \text { Cardiac anomomalies } \\
\text { - } & \text { Gastrointestinal anomalies } \\
\text { - } \quad \text { Musculoskeletal anomalies } & \text { Central nervous system anomalies }\end{array}$ & $\begin{array}{l}\text { High rate of pregnancy loss } \\
\text { Intrauterine growth restriction } \\
\text { Iatrogenic prematurity }\end{array}$ & [51-57] \\
\hline & & $\begin{array}{l}\text { Umbilical artery } \\
\text { hypoplasia }\end{array}$ & $0.04 \%$ & Maternal diabetes mellitus & $\begin{array}{ll}\text { - } & \text { Placentation anomalies } \\
\text { - } & \text { Abnormal placental cord insertion } \\
\text { - } & \text { Agemesis of corpus callosum } \\
\text { - } \quad \text { Cardiac anomalies } \\
\text { - } \quad \text { Genitourinary minor malformations } \\
\text { Polyhydramnios }\end{array}$ & Intrauterine growth restriction & [58] \\
\hline
\end{tabular}


Table 1. Cont.

\begin{tabular}{|c|c|c|c|c|c|c|}
\hline \multicolumn{2}{|l|}{ Pathology } & \multirow[b]{2}{*}{$\begin{array}{l}\text { Incidence } \\
\\
0.5 \%\end{array}$} & \multirow[b]{2}{*}{$\begin{array}{l}\text { Risk Factors } \\
\text { - Twin pregnancy (thoracopagus and } \\
\text { - } \quad \begin{array}{l}\text { Omphalopagus twins) } \\
\text { Thrombus obstruction, teratogens or } \\
\text { - Folic acid deficiency } \\
\text { Female fetuses }\end{array}\end{array}$} & \multirow[b]{2}{*}{$\begin{array}{ll}\text { Associated Pathology } \\
& \text { Anterior chest wall defects } \\
\text { Bilateral cleft lip and palate } \\
\text { Placental arteriovenous fistula } \\
\text { Edema } \\
\text { Heterotaxy syndrome } \\
\text { Trisomy } 18 \\
\text { Holoprosencephaly } \\
\text { Polyhydramnios } \\
\text { Omphalocele } \\
\text { Triploidy } \\
\text { Hypertrophic cardiomyopathy } \\
\text { Ectopia cordis } \\
\text { - } \\
\text { Detralogy of Fallot } \\
\text { Ductus venosus agenezia (DV) }\end{array}$} & \multirow[b]{2}{*}{$\begin{array}{l}\text { Adverse Outcome } \\
\text { Intrauterine growth restriction }\end{array}$} & \multirow[b]{2}{*}{$\begin{array}{l}\text { Reference } \\
\\
\text { [59-62] }\end{array}$} \\
\hline & $\begin{array}{l}\text { Supernumerary } \\
\text { vessels (Right } \\
\text { Umbilical Vein } \\
\text { Persistence) }\end{array}$ & & & & & \\
\hline & $\begin{array}{l}\text { Umbilical Cord } \\
\text { Cyst }\end{array}$ & $2-3 \%$ & Chromosomal anomalies & $\begin{array}{ll}\text { - } & \text { Fetal aneuploidies } \\
\text { Omphalocele } \\
\text { Vertebral defects } \\
\text { - } \quad \text { Imperforate anus } \\
\text { - } \quad \begin{array}{l}\text { Racheoesophageal and renal dystula } \\
\text { association }\end{array} \\
\quad \text { Angiomyxoma of the cord }\end{array}$ & $\begin{array}{l}\text { Rapid enlargement with the restriction of } \\
\text { blood flow and fetal distress requiring } \\
\text { emergency birth. } \\
\text { Torsion or thrombosis may cause fetal } \\
\text { demise }\end{array}$ & [63] \\
\hline & Cord Hematoma & $9 \times 10^{-5}$ & $\begin{array}{l}\text { - Umbilical blood sampling } \\
\text { - Fetal transfusion }\end{array}$ & Fetal bradycardia & $\begin{array}{l}\text { Modified umbilical artery flow } \\
\text { velocimetry, perinatal hypoxia, } \\
\text { miscarriage }\end{array}$ & {$[64,65]$} \\
\hline & $\begin{array}{l}\text { Cord } \\
\text { Varix/Aneurysm }\end{array}$ & $0.0011 \%$ & $\begin{array}{l}\text { Chromosomal anomalies } \\
\text { - } \quad \text { Single umbilical artery } \\
\text { - }\end{array}$ & $\begin{array}{ll}\text { - } & \text { Chromosomal anomalies } \\
\text { - } & \text { Anatomical abnormalities } \\
\text { - } & \text { Single umbilical artery }\end{array}$ & $\begin{array}{l}\text { Intrauterine death by aneurysm rupture } \\
\text { or varix thrombosis, fetal hydrops, SGA, } \\
\text { invalidated neurodevelopmental delay }\end{array}$ & {$[61,66,67]$} \\
\hline & $\begin{array}{l}\text { Cord Tumors: } \\
\text { angiomixomas, } \\
\text { mixosarcomas, } \\
\text { coriomixomas, } \\
\text { hemangiomas, } \\
\text { teratomas }\end{array}$ & Isolated cases & Twin pregnancy for teratomas & $\begin{array}{l}\text { Teratomas assoaciate: } \\
\text { - Omphalocele } \\
\text { - Trisomy } 13 \\
\text { Angiomyxoma assoaciate: } \\
\text { - Skin hemangiomas }\end{array}$ & $\begin{array}{l}\text { Intrauterine death due to torsion or } \\
\text { compression effect on umbilical cord } \\
\text { vessels }\end{array}$ & {$[68,69]$} \\
\hline \multirow[b]{2}{*}{$\begin{array}{l}\text { Coiling and } \\
\text { length } \\
\text { anomalies }\end{array}$} & $\begin{array}{l}\text { Excessive/Absent } \\
\text { Coiling }\end{array}$ & $4-5 \%$ & Abnormal placentation & Single umbilical artery & $\begin{array}{l}\text { Fetal growth restriction, congenital } \\
\text { anomalies, fetal heart rate abnormalities, } \\
\text { preterm birth, intrauterine death }\end{array}$ & [70] \\
\hline & $\begin{array}{l}\text { Abnormally } \\
\text { short/long Cord }\end{array}$ & $8.26 \%$ & Fetal malformations & $\begin{array}{l}\text { - Fetal malformations } \\
\text { - } \quad \text { Myopathic and neuropathic diseases }\end{array}$ & $\begin{array}{l}\text { Fetal inactivity in cases of short umbilical } \\
\text { cord, oligohydramnios, placental } \\
\text { pathology, fetal growth restriction, long } \\
\text { cord entanglement and intrauterine } \\
\text { asphyxia and fetal death. }\end{array}$ & [71-73] \\
\hline
\end{tabular}


Typically, the umbilical vessels lie parallel to the uterine wall as they penetrate the placental pole. Velamentous cord insertion is one of the most undiagnosed conditions in obstetrics. The velamentous cord insertion can be diagnosed by ultrasound, with a sensitivity of $69 \%$ to $100 \%$ and a specificity of $95 \%$ to $100 \%$, in the second trimester [24]. In the third trimester, this condition is also reflected through variable decelerations and abnormal fetal heart rate variability in a non-stress test; this is frequently associated with vasa praevia, the most reliable method of diagnosis for which is the real-time color Doppler transvaginal ultrasound examination, which can depict the umbilical vessel pathway, which crosses the internal os or passes at less than $2 \mathrm{~cm}$ from it; this is used to study the enddiastolic velocity of the umbilical artery. The single umbilical artery is associated with velamentous cord insertion in $12.5 \%$ of cases [23]. Our previous study, which included 43 cases of velamentous cord insertion from 18,500 deliveries in our department during a 6 year period, reported an incidence of associated single artery umbilical cord of $27.9 \%[25,26]$.

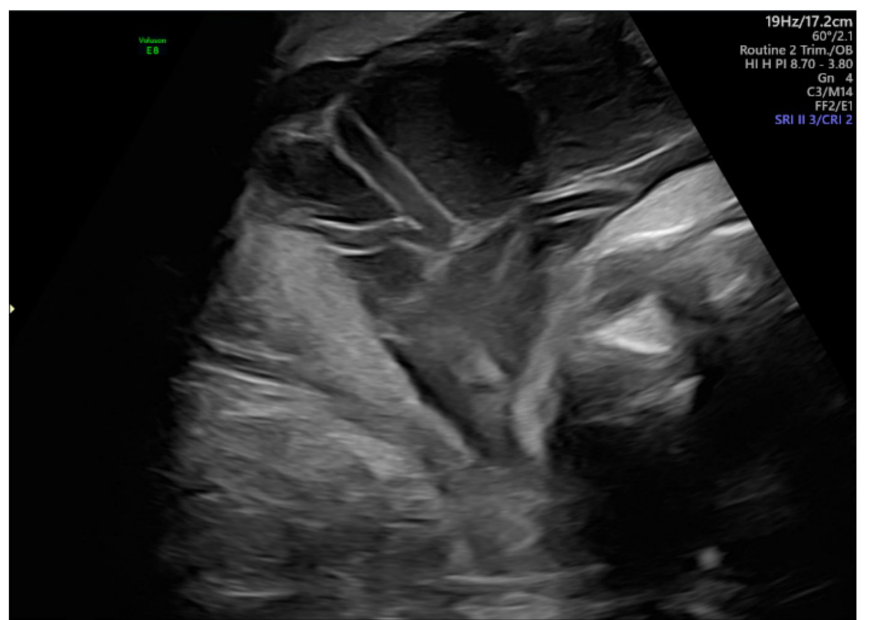

(a)

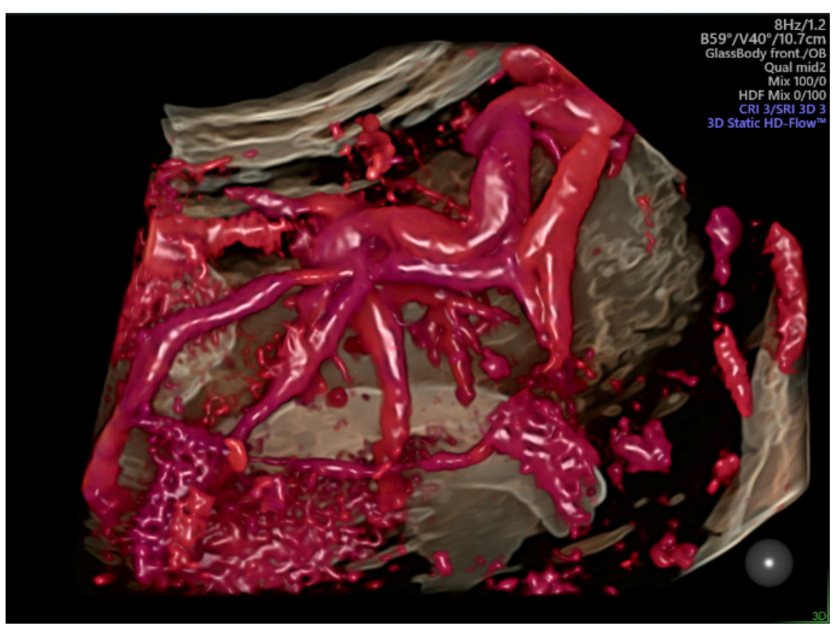

(c)

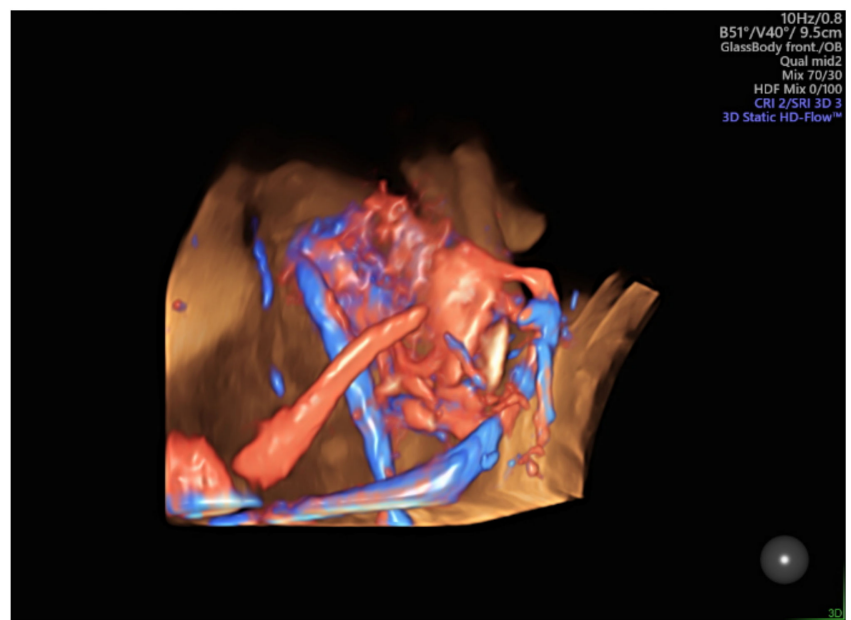

(b)

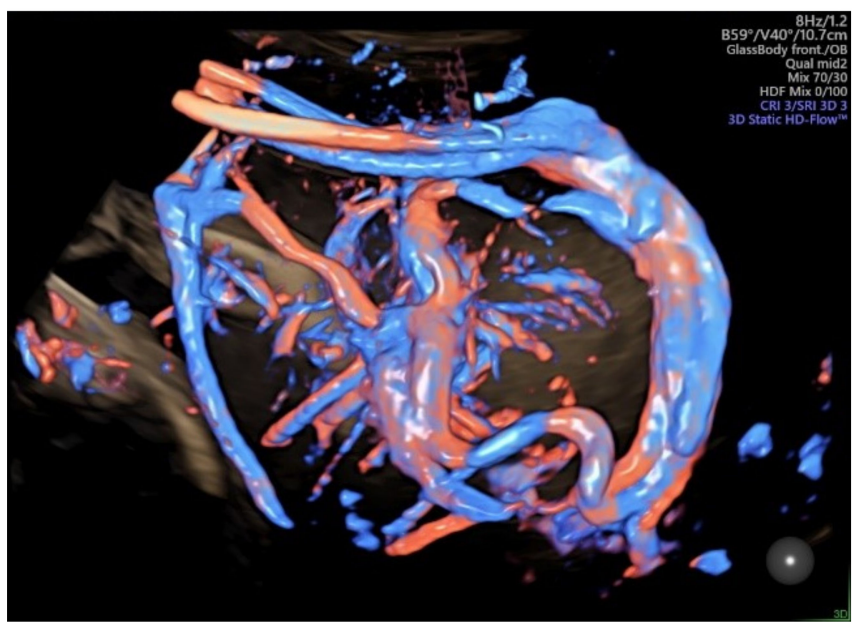

(d)

Figure 1. Velamentous cord insertion as (a) 2D scan and (b-d) 3D Static HD Flow imaging.

\subsection{Vasa Praevia}

Vasa praevia (Figure 2) are the umbilical vessels that cross the membranes of the lower uterine segment. The main risk associated with this abnormality is the rupture of vessels, even without rupture of the membranes resulting in fetal exsanguination or compression by the fetal presentation part. The antenatal diagnosis of vasa praevia increases the neonatal survival from $44 \%$ to $97 \%$ and improves the neonatal outcome [24,74]. Management 
particularities include a non-stress examination twice a week after 28 weeks of gestation, and cesarean delivery between 34-36 weeks of gestation [30].

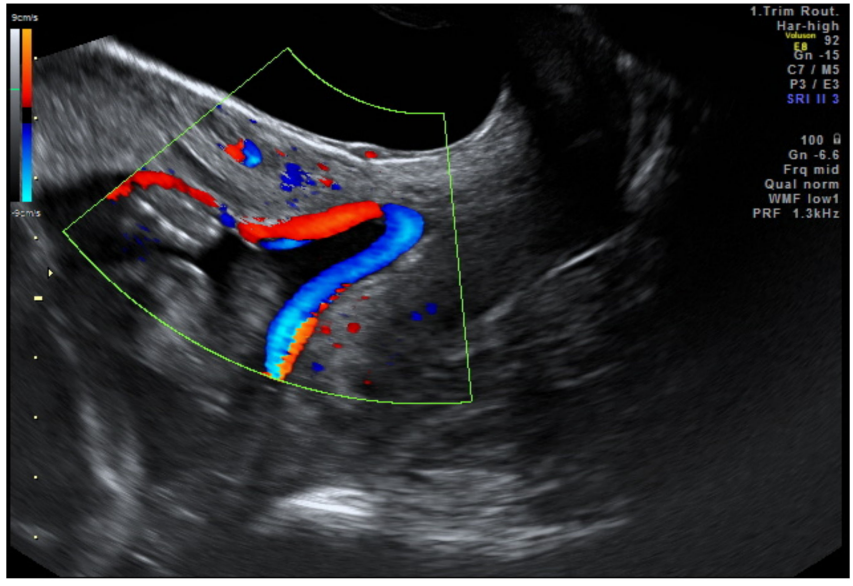

(a)

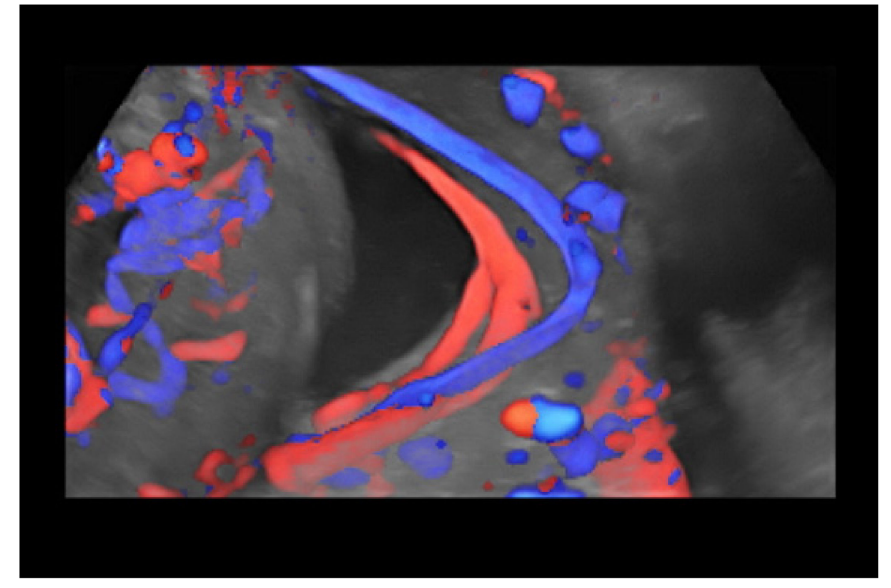

(b)

Figure 2. Vasa praevia as (a) 2D color Doppler ultrasound image and (b) 3D Static HD Flow imaging.

Three types of vasa praevia are described: type 1, resulting from velamentous cord insertion; type 2, presented in patients with bilobed or succenturiate lobed placenta; and type 3, boomerang-shaped vessels that cross the membranes along the placental margin, similar to resolving placenta praevia $[30,75,76]$. Antenatal diagnosis is based on transvaginal ultrasound examination and color Doppler flow mapping that can highlight umbilical vessels located $2 \mathrm{~cm}$ proximal to the cervical os [26,76]. Two-stage screening for vasa praevia, based on transvaginal sonography at 20-22 weeks of gestation, has recently been proposed by Zhang $\mathrm{W}$ et al. regarding pregnancies with velamentous cord insertion at the routine 11-13-week scan, and those with low-lying placenta at the mid-trimester scan; according to the authors, this method of screening would diminish stillbirths by $10 \%$ [31].

\subsection{Marginal Cord Insertion}

The defining element in describing marginal insertion of the umbilical cord (Figure 3) is for the cord insertion to be located within 2 or $3 \mathrm{~cm}$ of the placental edge [77-79]. Although many authors consider that there is no increased risk, complications such as intrauterine growth restriction, preeclampsia, preterm labor and progression to velamentous cord insertion were described [32,78]. According to Zhang $\mathrm{W}$ et al. [31], 9.5\% of cases diagnosed with vasa praevia during the second trimester scan presented marginal insertion of the umbilical cord during the first trimester screening.

\subsection{Anomalies of the Fetal Abdominal Cord Insertion}

Omphalocele and gastroschisis are the most common anterior abdominal wall defects (Figure 4). Prenatal ultrasound diagnosis of the non-liver-containing omphalocele is certain after 12 weeks of gestational age, whereas extrabdominal liver tissue could be observed transvaginally at 9-10 weeks of amenorrhea [80]. The omphalocele with intestinal content associates, in $60 \%$ of cases, with aneuploidies; as it can be part of a series of syndromes, it is mandatory that ultrasound assessment carefully looks for associated structural anomalies. Regarding umbilical cord insertion, the ultrasound differential diagnosis mainly targets gastroschisis in the presence of an unaffected insertion, adjacent to the abdominal wall defect. 


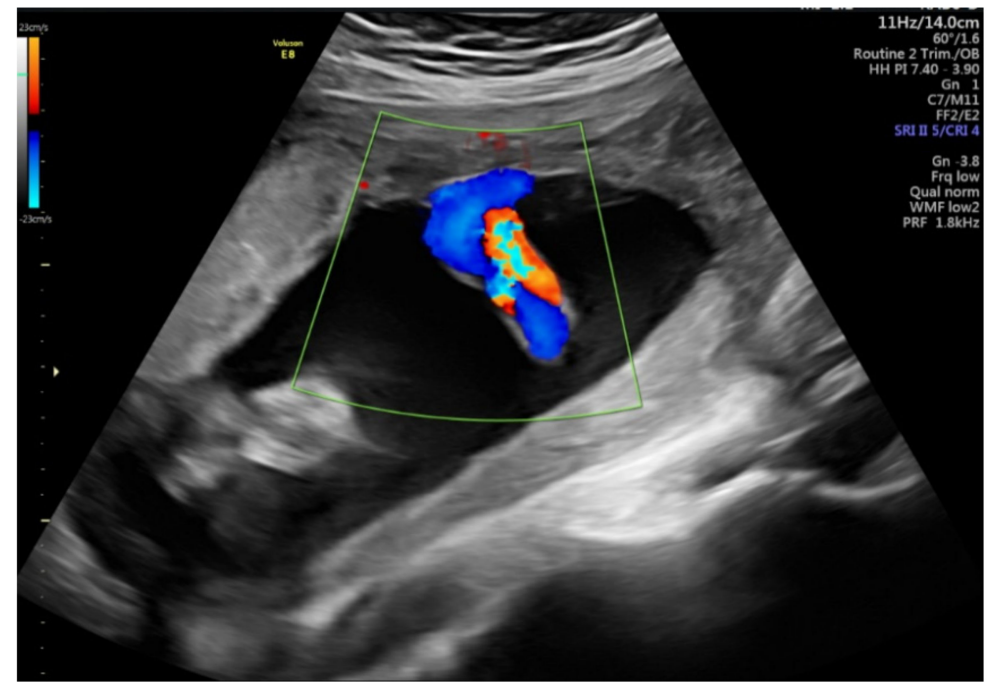

(a)

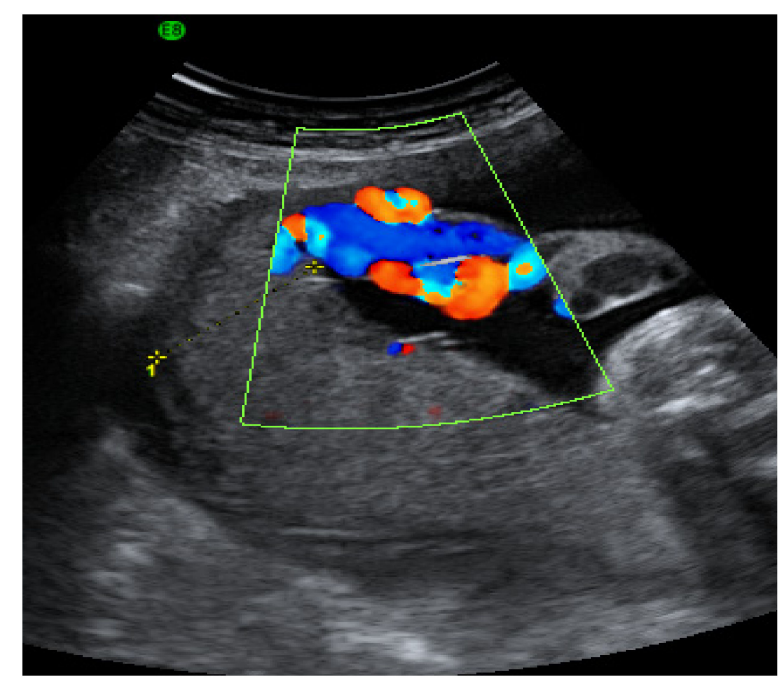

(b)

Figure 3. (a,b) Marginal insertion of the umbilical cord seen by color Doppler ultrasound.

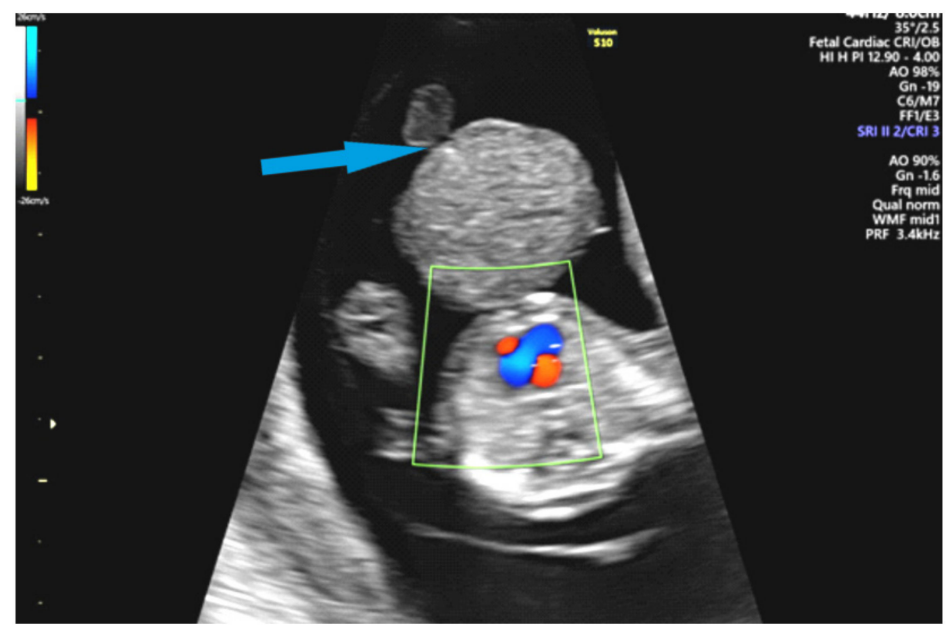

(a)

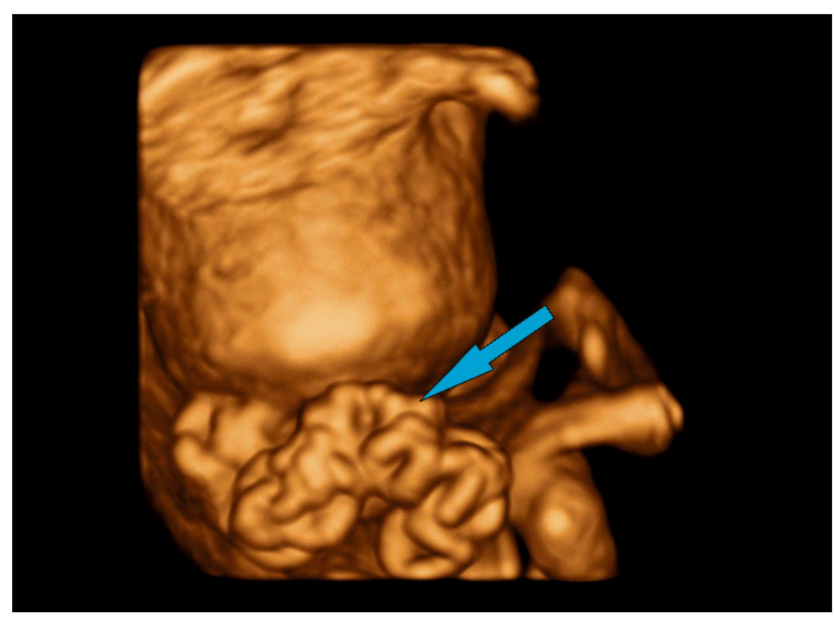

(b)

Figure 4. (a) Omphalocele and (b) gastroschizis ultrasound images of the $13^{+}$gestational week-old fetuses on 2D color Doppler and 3D reconstruction, respectively; the blue arrow indicates fetal umbilical cord insertion.

\subsection{Single Umbilical Artery}

There are four types of single umbilical artery: type 1, which corresponds to $98 \%$ of cases, and is characterized by the presence of an artery of allantoic origin and a normal vein. The association of the type 1 single umbilical artery with genitourinary anomalies is frequently described; type 2 , which corresponds to about $1.5 \%$ of cases, and is characterized by the presence of an artery of vitelline origins and a normal vein. The association with caudal regression syndrome and sirenomelia was described for this type; type 3 and 4, which are characterized by their rarity, consisting of two veins and one artery of allantoic origin in type 3 , and one persistent anomalous right umbilical vein and one artery in type 4, respectively. For these two types, the association of severe fetal anomalies with poor fetal prognosis is common; moreover, the risk of pregnancy loss is high [81].

Single umbilical artery can be diagnosed in the first trimester, but confirmation in the second trimester, by visualizing the intra-abdominal pathognomonic umbilical vessel present on only one side of the fetal bladder, is mandatory. The cord may also be velamentously inserted and thin (Figure 5) [82,83]. Along with the confirmed diagnosis, a special assessment of the possible associated anomalies (genitourinary, cardiac, gastrointestinal, 
musculoskeletal, central nervous system) is required [84]. The results of a large study that evaluated the associated conditions of single umbilical artery showed a higher prevalence of cardiac and renal anomalies in this group [85]. Additional invasive genetic studies have no justification in isolated cases of single umbilical artery, since the rate of aneuploidy among these cases is not increased; however, in cases of suspected additional fetal abnormalities, genetic invasive testing with karyotyping and microarray is recommended [86]. Regarding the management particularities, The Society of Obstetricians and Gynecologists of Canada recommendations include follow-up physical and sonographic evaluations of an eventual fetal growth restriction [87].

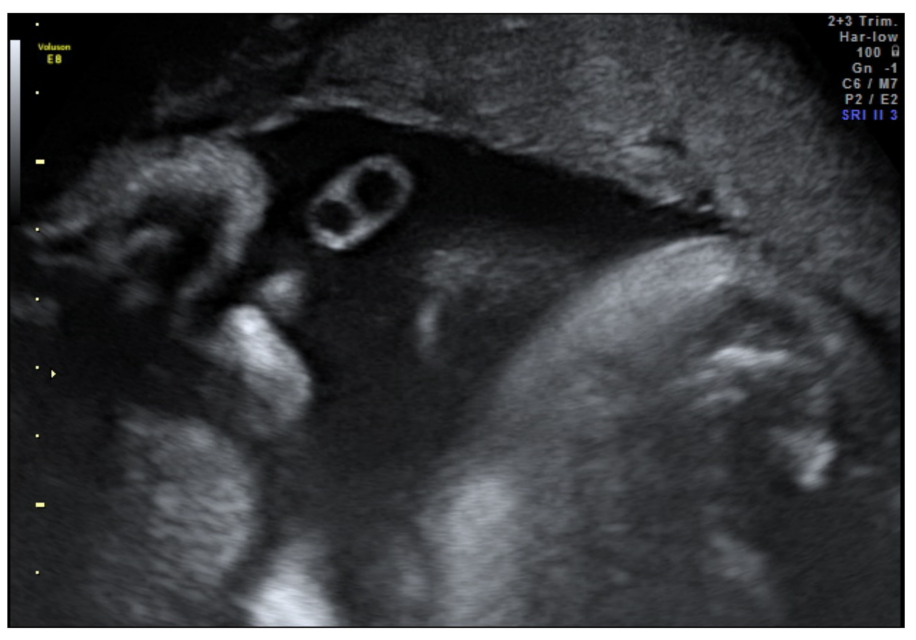

(a)

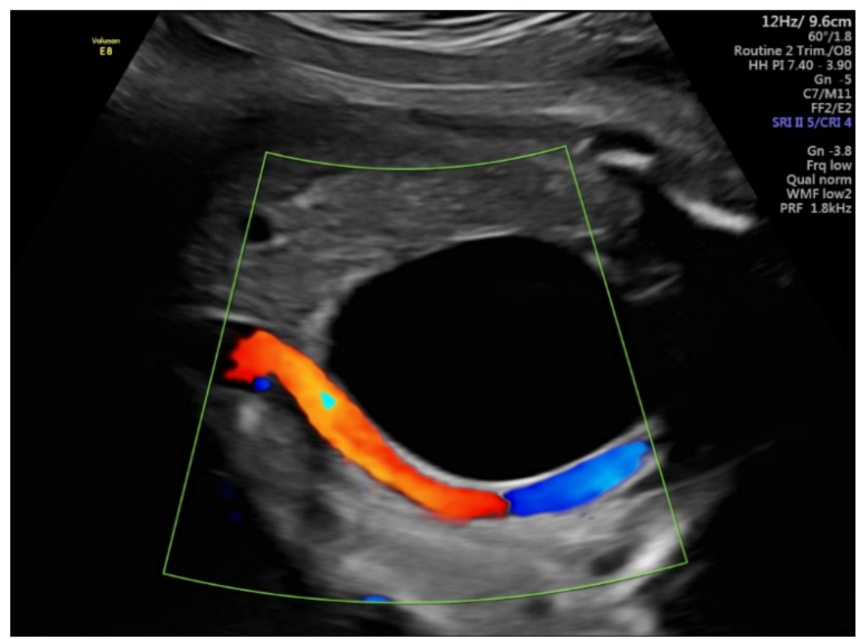

(b)

Figure 5. Single umbilical artery.(a) 2D imaging and (b) color Doppler imaging.

\subsection{Umbilical Artery Hypoplasia}

Umbilical artery hypoplasia (Figure 6) is defined by an artery caliber difference of over $50 \%$ and by the associated discordant umbilical artery-flow velocity with the resistance index almost always increased, or an absent end-diastolic flow in the smaller artery [58]. The clinical significance of this anomaly is not clearly established yet, but it seems to be associated with placental anomalies and abnormal placental cord insertion, trisomy 18, agenesis of corpus callosum, and cardiac and genitourinary minor malformations. Since umbilical artery hypoplasia could be a risk factor for fetal growth restriction, careful fetal anatomy and growing surveys are recommended.

\subsection{Supernumerary Vessels}

The typical model of multivessel cord most commonly encountered contains two arteries and two veins (Figure 7). A result of persistence of the right umbilical vein or of an abnormal splitting of an umbilical vessel, four-vessel umbilical cord is a common finding in conjoined twins and a very rare presence in singletons; this occurrence is usually associated with multiple and severe congenital anomalies, thus, pregnancy management depends on the associated findings $[59,60]$. The prenatal diagnosis of persistent right umbilical vein requires venous system scanning in 2D color-Doppler mapping; the transverse and longitudinal sections of the fetal abdomen reveal an abnormal course of the portal vein toward the stomach, the umbilical vein located lateral to the fetal gallbladder, and curving of the connection of the umbilical vein to the portal vessels towards the stomach [62]. 


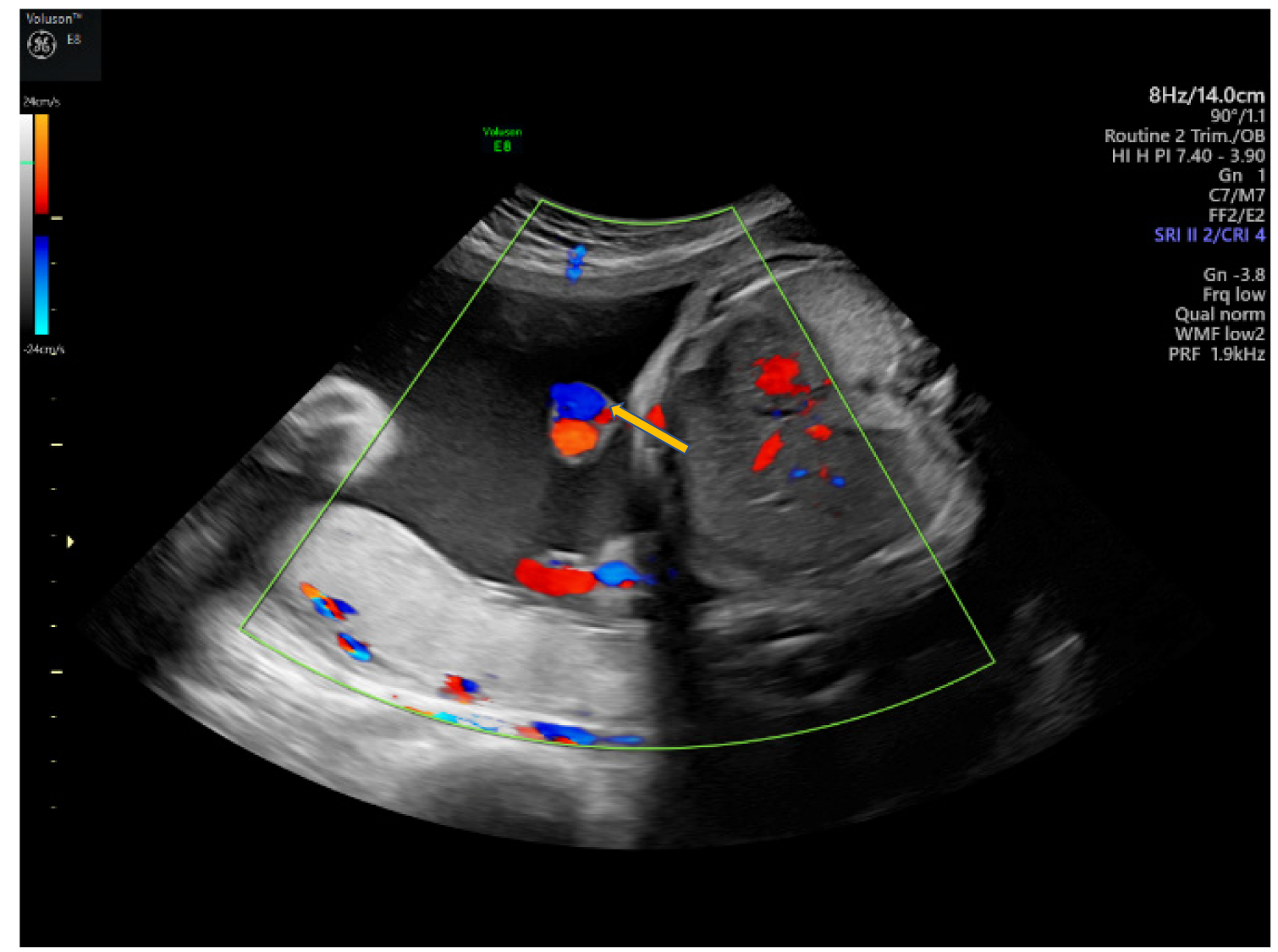

Figure 6. Hypoplasia of the umbilical artery (arrow).

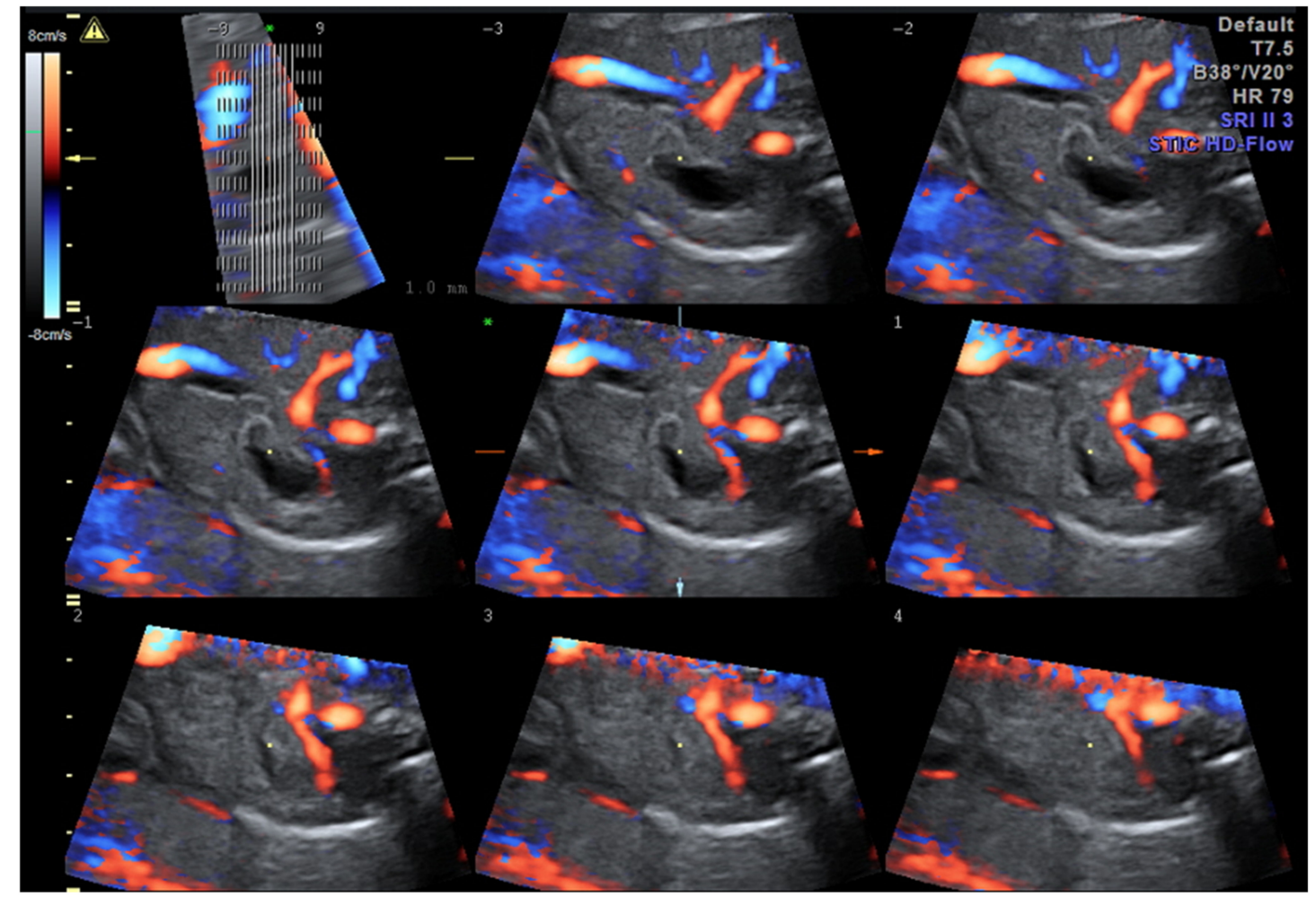

Figure 7. Two-dimensional imaging of a double umbilical vein. 


\subsection{Cord Knots}

A true umbilical cord knot (Figure 8 and Video S1) often remains undiscovered prenatally, the ultrasound visualization of the entanglement being an incidental finding. It is unusual for a knot to tighten, especially before the onset of labor. The prenatal suspicion of the presence of a true umbilical cord knot appears when a cross-section of an umbilical cord surrounded by a circular loop is observed on gray-scale ultrasound [88]; ultrasound achievements in 3D and Doppler mode easily sustain prenatal positive diagnosis, and distinguish from the false knots, which are more often suggested by the four-leaf clover appearance [17]. The specificity of the diagnosis is increased if the image persists even after the fetus has changed his position, and the same image is captured in two subsequent examinations. Unfortunately, the features are almost identical to the false knot, representing arterial vascular loops formed helically around the umbilical vein; therefore, confirmation and differential diagnosis requires the acquisition of three-dimensional volume colorDoppler of the suspected anatomical section. The compression of the cord by a constricted true knot can be detected by pulsed Doppler velocimetry of the umbilical artery [89]. The impact on the neonatal outcome of a prenatal diagnosis of a true umbilical cord knot has not been fully evaluated [49]; a recent publication noted that cord entanglement does not contribute to prenatal morbidity and mortality in monoamniotic twin pregnancies [41].

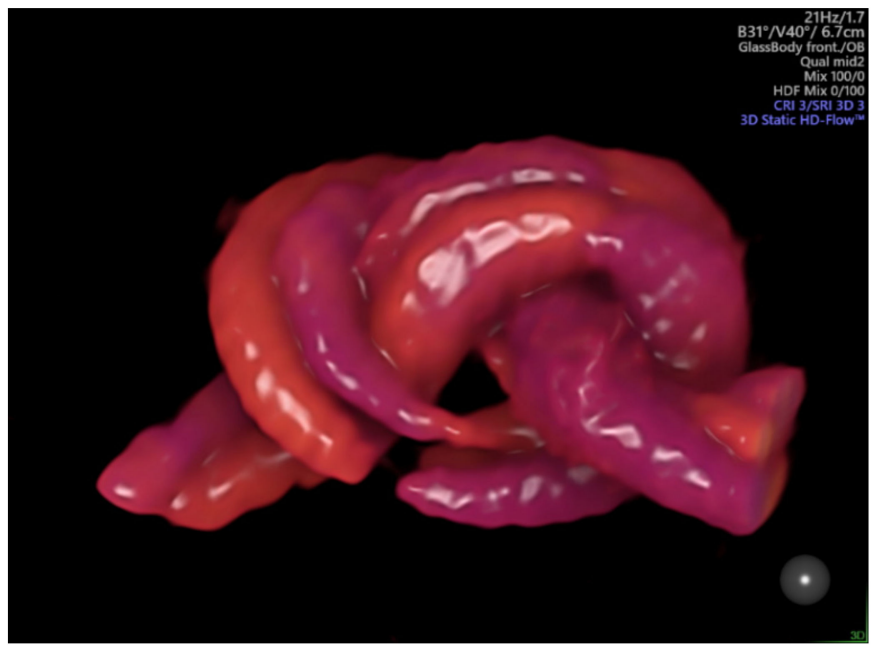

(a)

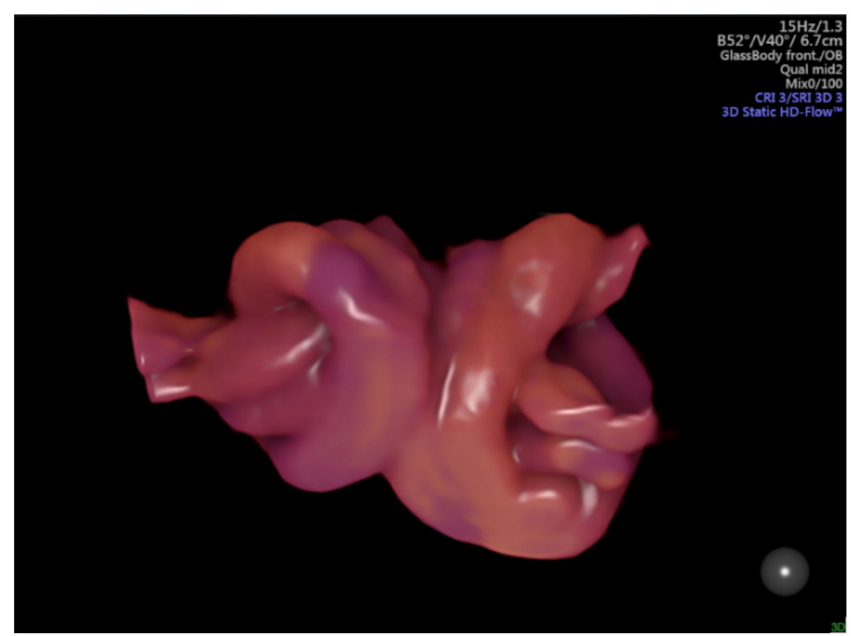

(c)

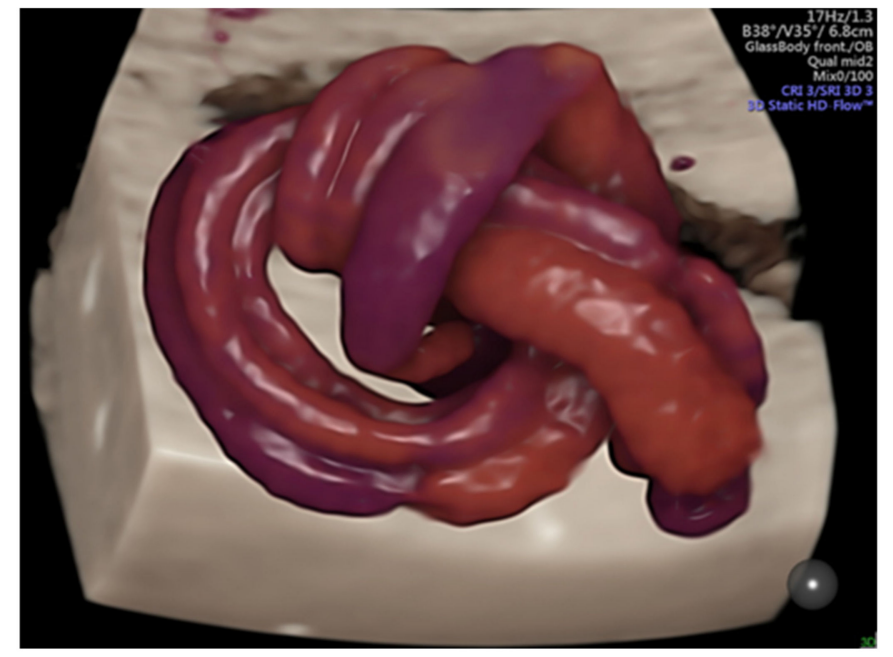

(b)

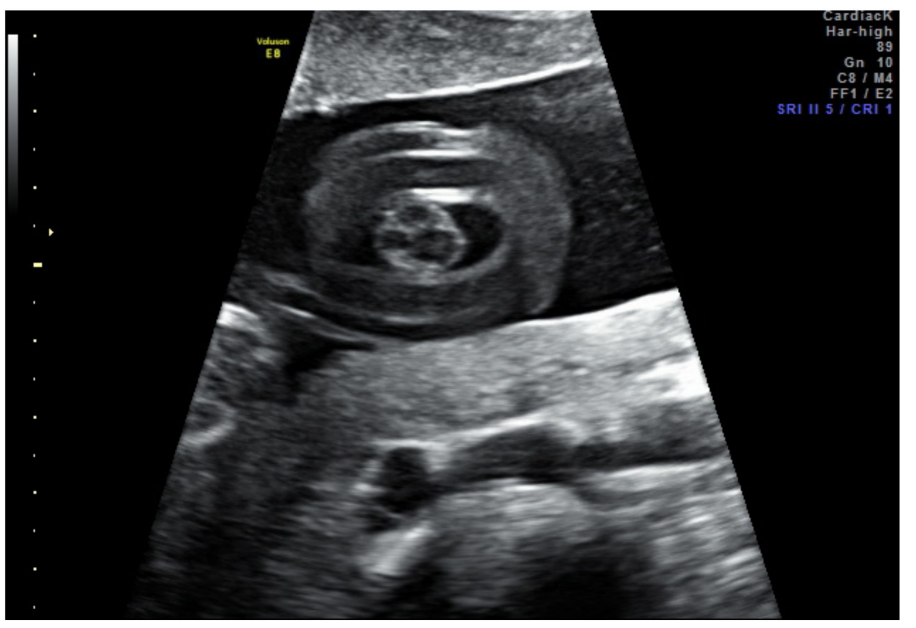

(d)

Figure 8. Images of true umbilical knots as (a-c) 3D Static HD Flow imaging and (d) 2D ultrasound image. 
We have revealed, in a previous study [17], an umbilical cord knot incidence of $0.71 \%$, with only $12 \%$ of them being antepartum diagnosed by ultrasonography; a false knot was recorded in $0.02 \%$ of cases. Most cases of true umbilical cord knots were diagnosed in women in their second and third pregnancies, at $42.8 \%$ and $30 \%$, respectively. None of the patients with antepartum diagnosis of umbilical knot accepted vaginal delivery. Umbilical cord length was over $30 \%$ higher than the mean in these patients.

\subsection{Nuchal Cord}

The actual impact of the nuchal cord (Figure 9 and Figure S1) in the pregnancy outcome is controversial. The number of loops is inversely correlated with incidence, and increases linearly with every week of gestation [42]; two or more loops growing exponentially is concerning. A classification regarding the locked and unlocked pattern was described in 1997 , and is based on the position of the placental end of the umbilical cord in relation with the umbilical end [90]. Using gray-scale ultrasound imaging, the diagnosis sensitivity is about 70\%; this is increased by color Doppler and tridimensional technology to about $97 \%$, and leads to specificity reaching 96\% [91,92]. The accuracy is high, but as Peregine concluded in his article [50] the ultrasound diagnosis of the nuchal cord will only be useful if we also include predictors of a complicated outcome, such as the divot sign, which represents indentation of the subcutaneous tissue, resulting from compression of the nuchal cord on the fetal neck, imaging in the longitudinal posterior plane [93]. Recently, Sherer DM et al. defined "complex umbilical cord entanglement" as cases of true knot of the umbilical cord, cases of $\geq 3$ loops of nuchal cords, or any combination of a true knot and nuchal cord in singletons [92]. In monoamniotic twins and in fetuses with intrauterine growth restriction, the measurement of the flow velocity of the cord can dictate future management. None of the guidelines of prenatal ultrasound examination include routine screening for nuchal cords, since they are considered an incidental normal finding.

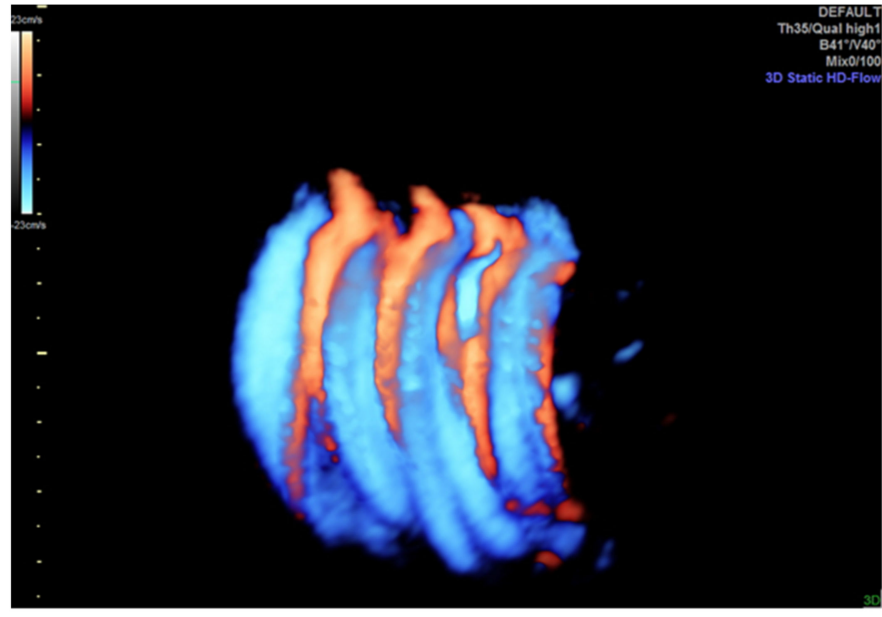

(a)

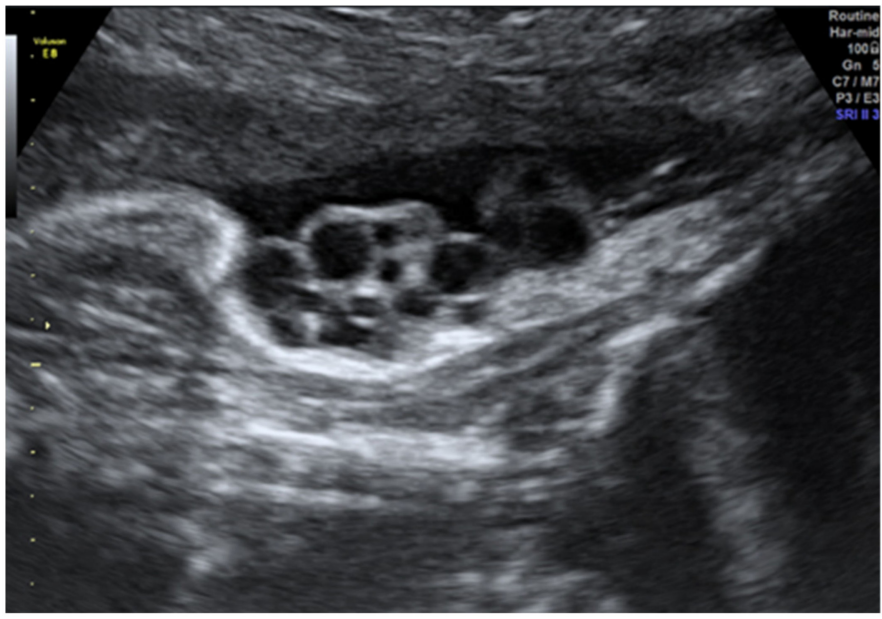

(b)

Figure 9. Example of a complex nuchal cord counting 5 loops (a) 3D Static HD Flow imaging and (b) 2D ultrasound image.

\subsection{Cord Strictures}

Stricture of the umbilical cord is an uncommon condition characterized by a sharp narrowing of the umbilical cord, usually associated with long umbilical cords or hypercoiling of the cord; an isolated stricture or multiple strictures can narrow the umbilical cord [94]. Intrauterine growth restriction and intrauterine fetal death has been repeatedly associated with this condition. An article published by French et al. in 2005 suggests a recurrence in pregnancies involving cord strictures [95]. The major pathological characteristics are the absence of the Warton's jelly, stenosis, obliteration of cord vessels at the narrow segment, and intravascular cord thrombosis. The cause of umbilical stricture is unknown [50]. An 
accurate antenatal diagnosis of this umbilical cord anomaly is a challenge for most obstetricians; the Doppler flow velocimetry with modified values could be predictive; however, a sudden change in fetal activity can also require consideration.

\subsection{Cord Hematoma}

On prenatal ultrasounds, umbilical cord hematomas are seen as tumors (Figures 10 and S2), presenting as a solid-appearing mass attached to, or within, the umbilical cord, but without the internal color spots of vessels. These pseudotumors, can occur spontaneously, but are more frequent a result of cordocentesis or fetal transfusion. Being seen on ultrasounds in close relation with the umbilical cord, hematomas can have different sizes and shapes depending on the appearance time. Acute hematomas are isoechoic/heterogeneous, while chronic hematomas are hypoechoic/anechoic. As a consequence, modified umbilical artery flow velocimetry can be observed due to the compression effect [64], along with fetal bradycardia. Usually an incidental finding, pregnancies with cord hematoma require special monitoring by blood flow velocity and non-stress tests twice weekly.

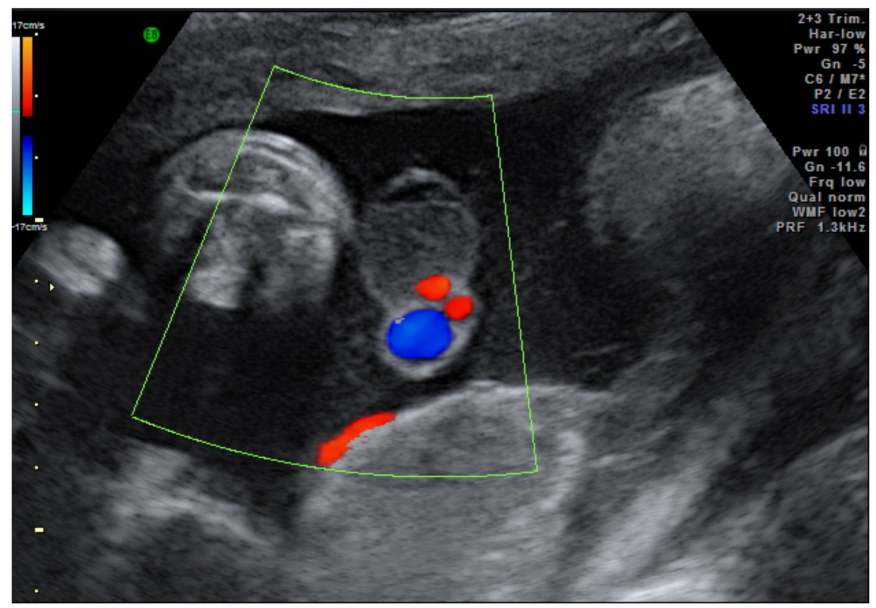

(a)

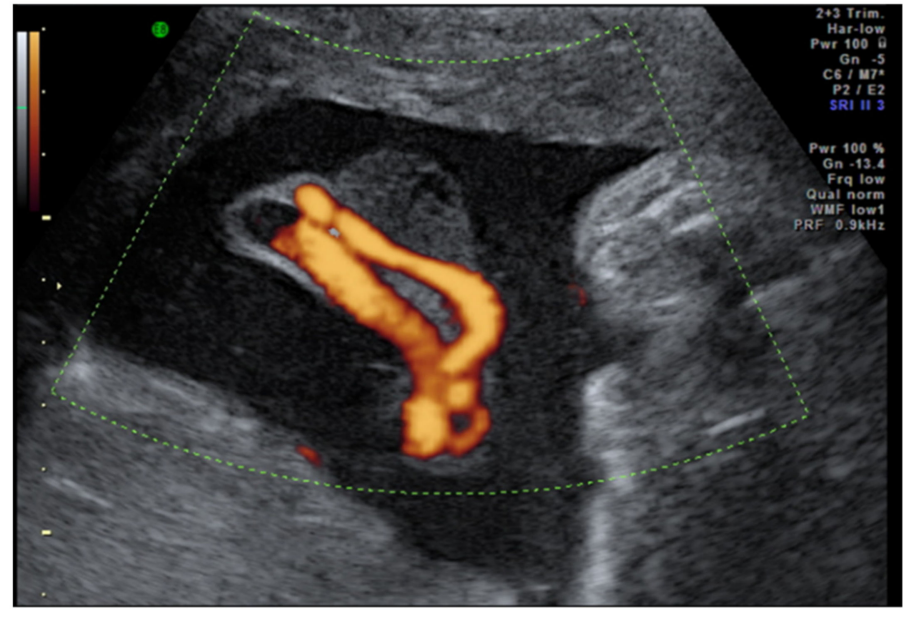

(b)

Figure 10. Cord hematoma seen on (a) 2D color Doppler imaging and (b) power Doppler imaging.

\subsection{Cord Varix and Aneurysm}

Focal dilatation of the umbilical artery or vein are rare and have frequently been associated with fetal demise [96]. Upon prenatal ultrasound examination, cord varix can be seen as a cyst-like structure with venous flow on a Doppler examination. A value greater than $9 \mathrm{~mm}$ or 1.5 -fold dilatation, compared to the normal adjacent segment of the umbilical cord, is required for the diagnosis [97]. The main complication is the thrombosis of the varix with hydrops fetalis as a direct consequence, but the recent multicenter cohort study of Novoa et al. sustains the association with chromosomal and/or anatomical abnormalities in $20 \%$ of cases [98]. Antenatal ultrasound reveals a cystic/elongated dilatation in close relation to the umbilical artery with non-pulsatile flow on a Doppler exam (Figures 11 and S2).

\subsection{Cystic Abnormalities-True Cysts and Pseudocysts}

Upon ultrasound examination, both true and pseudocysts appear as hypoechoic lesion included in the umbilical cord, near the vessels. True cysts can be allantoically formed by the persistence of the urachus and are frequently associated with urachal anomalies and communication between the cyst and fetal bladder [99]; they can also be formed in an omphalomesenteric manner by the persistence of the vitelline duct, and present a difficult prenatal diagnosis [100]. The position of the allantoic cysts in the proximity of the fetal abdominal wall may be confounded with an anterior abdominal wall defect. In clinical practice, the risk related to this condition is rapid enlargement with the restriction of blood flow and fetal distress, requiring emergency birth. The particularities of the management 
of these cases include a weekly follow-up of umbilical artery velocimetry, and urological neonatal consultation.

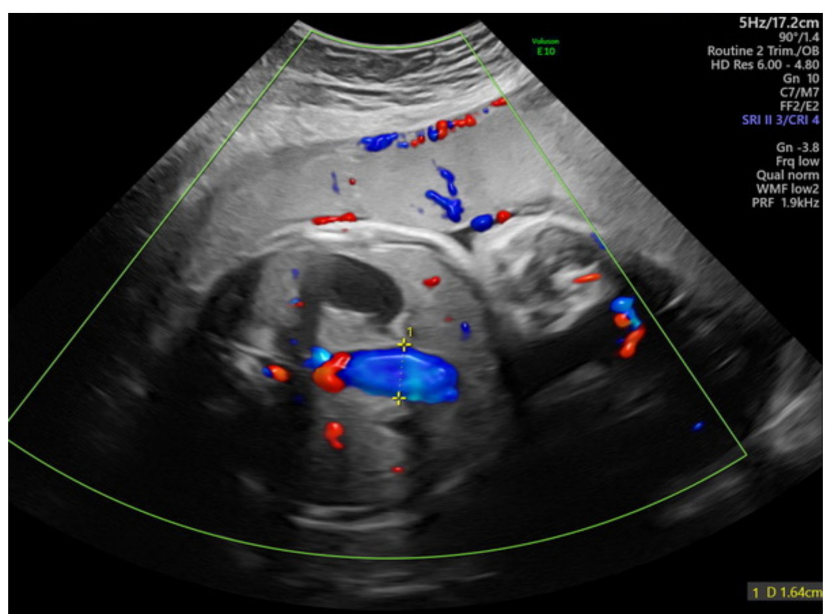

(a)

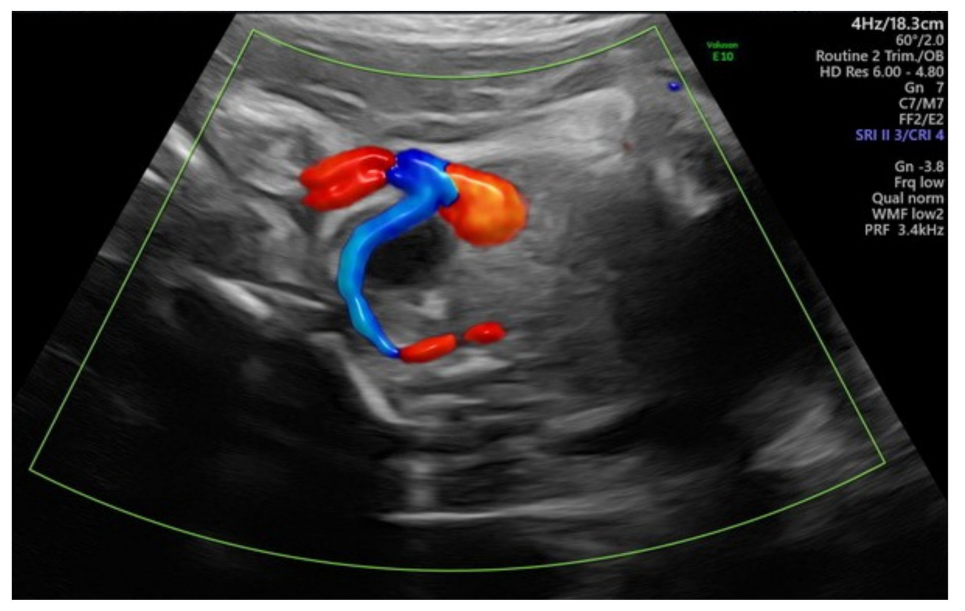

(b)

Figure 11. Two dimensional color-Doppler of umbilical vein varix typically occurring in the intraabdominal portion of the vein. (a) transverse abdominal section and (b) oblique vesical section.

Umbilical cord pseudocysts are more common compared to true cysts (Figures 12 and S3) [63]; they appear as a large, hypoechoic mass situated near to the fetal insertion or in a free loop of the cord, and compared with the yolk sac, present a less intense hypoechogenic wall, and are intra-amniotic. Differential diagnosis with an aneurismal umbilical vessel is made by color-Doppler. Regarding the strong association of pseudocysts with chromosomal abnormalities, their multiloculated aspect and their persistence over the 14th week must lead to prenatal karyotyping, detailed examination of fetal anatomy, and routine fetal growth evaluation [101]. Umbilical cord cysts diagnosed in the first trimester [63] usually have a rapid resolution, and their development is related with the cord coiling and formation of physiological midgut hernia. In case of large dimensions and severe fetal impact, aspiration of the cyst is indicated [102], but expectant management is sufficient in most cases.

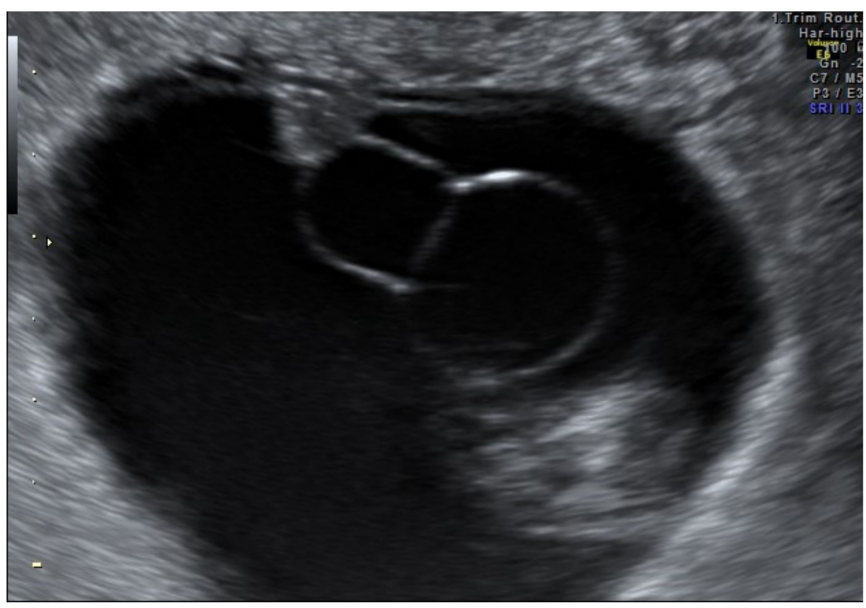

(a)

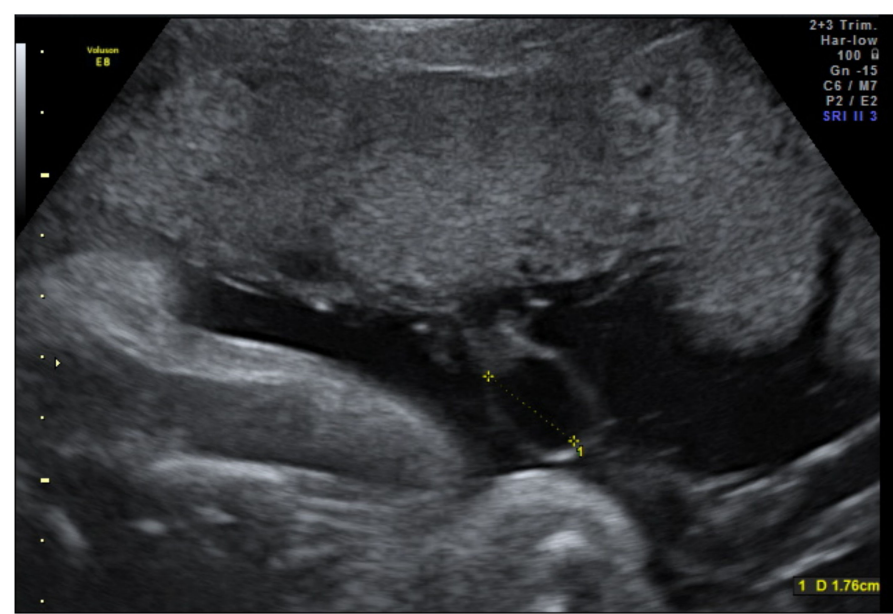

(b)

Figure 12. Cyst observed in the 2D ultrasound $(\mathbf{a}, \mathbf{b})$.

\subsection{Teratoma}

Teratomas are rare heterogeneous tumors, that contain tissue from the three germ-cell layers, suspected to be small acardiac twins [68]. The cases detected prenatally in $[103,104]$ 
were terminated, so the natural course of these pregnancies remained unknown. Differential diagnosis is made with placental teratoma that is located closely to the placental tissue or surrounded by it $[69,105]$.

Angiomyxoma is an extremely rare tumor that presents as a hyperechogenic mass attached to the umbilical vessels; often associated with a pseudocyst, the blood vessels within the tumor have low flow velocities [106,107].

\subsection{Coiling and Length Abnormalities}

The role of coiling is to protect the cord from compression, kinking, and torsion, thus assuring an adequate blood supply to the fetus. Hypocoiled (Figure S4) or hypercoiled cord has also been associated with an increased rate of neonates that are small for their gestational age, congenital anomalies, fetal heart rate abnormalities, preterm birth and intrauterine death (Figure 13). Sonographic measurement of the number of complete coils per centimeter has an important degree of difficulty, and there are no prenatal, gestationalage-specific standard reference values [108].

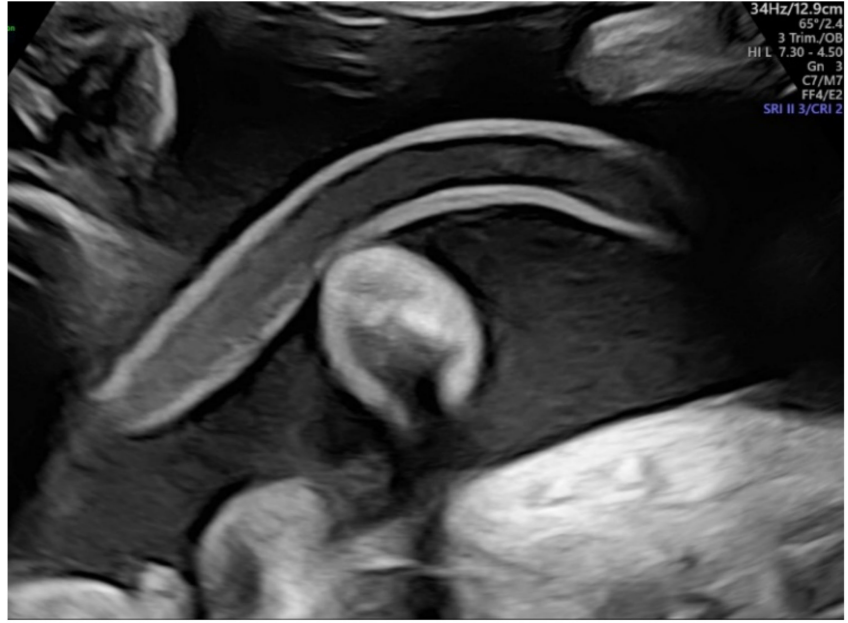

(a)

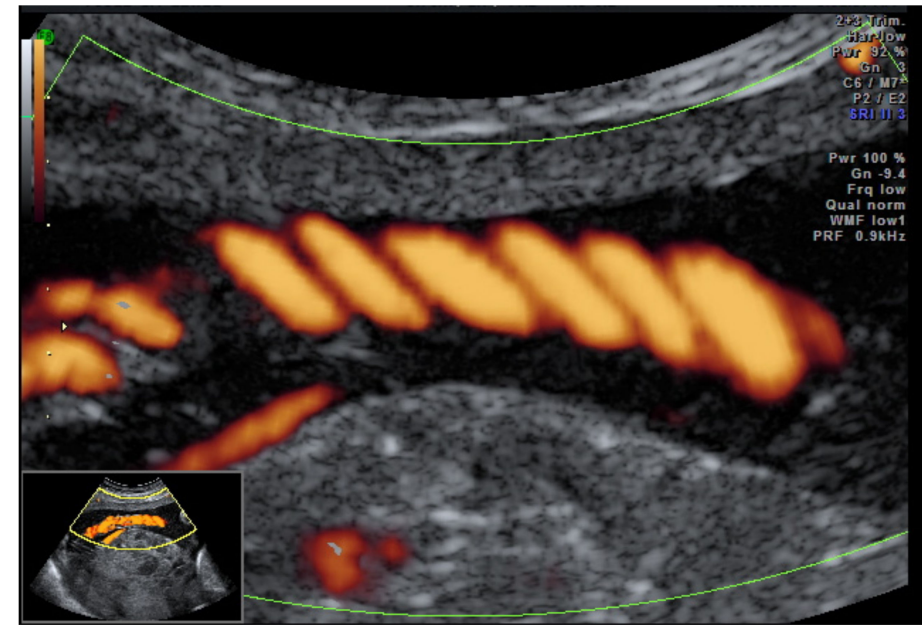

(b)

Figure 13. Coiling abnormalities: (a) lax cord and (b) hyperspiralized cord.

Cord length increases proportionally with the gestational age. A long umbilical cord is considered if the length exceeds $70 \mathrm{~cm}$ and it is considered short if measures less than $30 \mathrm{~cm}$ [71]. Short umbilical cord can be associated with fetal inactivity, fetal malformations, myopathic and neuropathic diseases, oligohydramnios, and some syndromes [72]. Long cord is associated with placental lesions, fetal growth restriction, intrauterine hypoxia, and even fetal death; additionally, cord accidents, entanglement, knotting, and prolapse can lead to long-term adverse neurologic outcomes. Antenatal ultrasound assessment of umbilical cord length is extremely difficult and uncertain.

\section{Proposed Classification}

Our recommendation regarding umbilical cord anomaly classification includes two classes:

Class $S$ of structural abnormalities of the umbilical cord, and Class $P$ of positional abnormalities. Due to the fact that the localization of most anomalies influences perinatal outcome, aiming to simplify the reporting and increase the accuracy of umbilical cord anomaly diagnosis, we encoded fetal insertion, free umbilical cord and placental insertion (Tables 2 and 3). 
Table 2. Proposed classification of the Umbilical Cord Anomalies.

\begin{tabular}{llll}
\hline Proposed UCA Class & Clinical Useful UCA & Incidental Finding of UCA & Clinical Un-Useful UCA \\
\hline Class S & Velamentous Cord Insertion & Cord Tumors & $\begin{array}{l}\text { Right Umbilical Vein } \\
\text { Persistence }\end{array}$ \\
\hline Class S & Vasa praevia & Umbilical Cord Cyst & Isolated Cord Varix \\
\hline Class S & Omphalocele & Cord Hematoma & Excessive /Absent Coiling \\
\hline Class S & Single Umbilical Artery & Cord Strictures & Abnormally short/long Cord \\
\hline Class P & Cord Knot & Funic Cord Presentation & Nuchal Cord $<3$ loops \\
\hline Class P & & Eccentric/Marginal Cord Insertion & \\
\hline
\end{tabular}

Table 3. Management of the UCA classified by clinically usefulness.

\begin{tabular}{|c|c|c|}
\hline & Type of Anormaly & Management \\
\hline \multirow{5}{*}{ Clinically Useful } & Velamentous Cord Insertion & Fetal anatomic survey, serial assessment of fetal growth every 4 to 6 weeks \\
\hline & Vasa praevia & $\begin{array}{l}\text { Administration of corticosteroids at } 28-32 \text { weeks for accelerate } \\
\text { pulmonary maturation } \\
\text { Hospitalization at } 30-32 \text { weeks in tertiary care unit } \\
\text { Elective caesarean section prior to membrane rupture, at } 34-36 \text { weeks } \\
\text { Aggressive resuscitation of the neonate in case of ruptured vasa praevia }\end{array}$ \\
\hline & Omphalocele & $\begin{array}{l}\text { Karyotyping (amniocentesis), therapeutic abortion or expectant management } \\
\text { with fetal anatomic survey and serial assessment of fetal growth }\end{array}$ \\
\hline & $\begin{array}{l}\text { Single Umbilical } \\
\text { Artery/Umbilical Artery } \\
\text { Hypoplasia }\end{array}$ & $\begin{array}{l}\text { Detailed fetal anatomical survey, assessment of the placenta and umbilical } \\
\text { cord; cell-free DNA screening for isolate SUA/invasive karyotype with } \\
\text { microarray for non-isolated SUA; monitor for growth restriction with } \\
\text { Doppler velocimetry assessment of the single/larger diameter } \\
\text { umbilical artery }\end{array}$ \\
\hline & Cord Knot & $\begin{array}{l}\text { Close fetal monitoring in the third trimester by serial nonstress tests, } \\
\text { biophysical profile scoring and Doppler assessment } \\
\text { Elective cesarean delivery at 38-weeks of gestation }\end{array}$ \\
\hline \multirow{6}{*}{ Incidental finding } & Cord Tumors & $\begin{array}{l}\text { Detailed fetal anatomical survey and monitoring for partial occlusion of } \\
\text { umbilical blood flow }\end{array}$ \\
\hline & Umbilical Cord Cyst & $\begin{array}{l}\text { Detailed fetal anatomical survey and monitoring cystic diameter, and } \\
\text { possible obliteration of umbilical blood flow; invasive karyotype with } \\
\text { microarray for non-isolated cysts; repeated fetal growth assessment in the } \\
\text { third trimester. }\end{array}$ \\
\hline & Cord Hematoma & $\begin{array}{l}\text { Monitor for growth restriction and fetal distress particularly during labor } \\
\text { Check for reduction in fetal movements } \\
\text { Cesarean section is highly recommended }\end{array}$ \\
\hline & Funic Cord Presentation & Carefully assess membrane rupture \\
\hline & $\begin{array}{l}\text { Eccentric/Marginal Cord } \\
\text { Insertion }\end{array}$ & Monitor for growth restriction and fetal distress particularly during labor \\
\hline & Cord Strictures & Monitor for growth restriction and fetal distress particularly during labor \\
\hline \multirow{4}{*}{ Clinically Unuseful } & $\begin{array}{l}\text { Right Umbilical Vein } \\
\text { Persistence }\end{array}$ & $\begin{array}{l}\text { Careful examination of fetal anatomy and exclusion of conjoined twins in } \\
\text { twin pregnancy }\end{array}$ \\
\hline & Cord Varix & $\begin{array}{l}\text { Frequent nonstress testing and ultrasound surveillance. Cases associated } \\
\text { with IUGR should be delivered when fetal lung maturation is achieved, at } \\
34-36 \text { weeks }\end{array}$ \\
\hline & $\begin{array}{l}\text { Abnormal coiling and } \\
\text { length of umbilical cord }\end{array}$ & $\begin{array}{l}\text { Close fetal monitoring in the third trimester by serial nonstress tests, } \\
\text { biophysical profile scoring and Doppler assessment }\end{array}$ \\
\hline & Nuchal Cord & Carefully assessment of labor \\
\hline
\end{tabular}




\section{Discussions}

This paper reviews the most important aspects of the structural abnormalities of the umbilical cord, as determined by prenatal ultrasound, highlighting their clinical relevance for the management of these high-risk pregnancies.

Beginning with the normal structure of the umbilical cord, with two arteries branching off the left and right internal iliac arteries, and one vein formed by the confluence of chorionic veins at the chorionic plate, the continuous, increasing incidence and update on the aspects of umbilical cord abnormalities make this subject an ever-topical one.

Compared with pregnancies without abnormalities of the umbilical cord, the presence of this pathology induces an increased risk of polyhydramnios, birth before 34 weeks, placental abnormalities and low birth weight; implicitly, there is an increased index of cesarean delivery due to the presence of fetal distress, increased prenatal mortality rate and higher admission to neonatal intensive care.

Current guidelines highlight the importance of determining the number of vessels and fetal cord insertion. However, lately, the focus has been increasingly on the diagnosis of other abnormalities of the umbilical cord, especially in terms of their frequent association with numerous fetal abnormalities. The normal fetal and placental insertions of the umbilical cord and its structure should be documented after 12 weeks of gestation. Umbilical cord anomalies are usually seen clearly after 20 weeks using the standard two-dimensional technique in transverse and longitudinal planes; however, the image is improved by color Doppler and three-dimensional imaging techniques [109]. A more detailed examination includes the description of the fetal and placental insertion sites, the helical pattern of the umbilical arteries, and the characteristics of the Warton's jelly [71]. The extended analysis of the umbilical cord offers the advantage of identifying and preventing adverse perinatal outcomes associated with certain umbilical cord abnormalities such as thinness, velamentous insertion, vasa praevia, abnormal coiling, cysts and tumors [110].

The obstetrician is faced with an ethical dilemma when observing an unusual coiling of the umbilical cord that may indicate a true umbilical cord knot—-the "hanging noose" signupon ultrasound examination, without other specific symptoms and abnormal sonographic findings and normal Doppler assessment (when the measurements are performed in a free cord loop and the Doppler indices—pulsatility; resistance; and the peak-systolic/enddiastolic velocity ratio are within normal ranges [9]): the decision must be made to either inform the patient of the suspicion of a true umbilical cord knot and the risks related to this condition, and the decision to preventing patient's anxiety and iatrogenic preterm birth by close and apparently unjustified monitoring. In fact, the debate could be resumed to positioning this pathology among clinically relevant UCA or among incidental findings. The decision belongs to International Societies that have to respond to the evident need of clarify the feasibility and strategies of the ultrasound antenatal scan for detection of the umbilical cord anomalies. Practically, HD flow Doppler should be used at the site of the coiling when an umbilical cord knot is suspected. If the technology or operator experience are not available at the screening site, suspected cases should be referred to fetal medicine units.

We propose a significant change in the practice of fetal ultrasound, which is likely to prove useful. A prospective study based on our proposed classification is the next step to be undertaken. Our article is written after 10 years of detailed and extensive assessment of the umbilical cord during the entire gestational period; looking for anomalies is the first step in discovering them, and the changed medical attitude may prevent, over time, many adverse pregnancy outcomes.

\section{Conclusions}

Although we acknowledge that some umbilical cord anomalies might develop later in pregnancy and may be obscured from view (about $0.3 \%$ ), we consider that marginal or velamentous cord insertion should be routinely performed at the first and second trimester ultrasound screening for placental umbilical cord insertion, and trans-vaginal ultrasound 
color-Doppler assessment of internal cervical os-during the mid-trimester scan, at the time of cervical length measuring-when screening for premature delivery, at least in cases of low-lying placentas. Umbilical cord insertion should be assessed starting with the first trimester and continuing into the second trimester. Even if the incidence of some of the umbilical cord abnormalities is low, the fact that many of these are life threatening-and the cause of prenatal and intrapartum fetal morbidity and mortality (vasa praevia, cord knot) - we consider that it is mandatory to introduce this in the evaluation guidelines of both cord insertions, and scanning of the cord between the insertion sites during the ultrasound second trimester screening for fetal abnormalities; from our experience, most knots are formed up to this gestational age. The amount of amniotic fluid in the second trimester allows easy depiction of cord anomalies.

Supplementary Materials: The following are available online at https:/ /www.mdpi.com/article/10 .3390/ diagnostics12020236/s1, Figure S1: scanning images of various nuchal cords observed in the clinical practice; Figure S2: three-dimensional imaging of varix cords; Figure S3: cystic abnormalities; Figure S4: coiling pathologies: lax cord; Video S1: NOD_26.

Author Contributions: Conceptualization, R.E.B.; formal analysis, R.E.B., I.D. and B.M.M.; investigation, A.V., V.D., O.M., C.G. and R.V.; methodology, R.E.B., V.D., C.G. and D.P.-O.; resources, R.E.B. and D.P.-O.; software, A.M.I.; supervision, R.E.B.; validation, A.V., O.M. and R.V.; visualization, I.D. and A.M.I.; writing—original draft, R.E.B. and B.M.M.; writing—review \& editing, R.E.B. and B.M.M. All authors have read and agreed to the published version of the manuscript.

Funding: This research received no external funding.

Institutional Review Board Statement: The study was conducted according to the guidelines of the Declaration of Helsinki, and approved by the Ethics Committee of the University Emergency Hospital (approval code 73317 and approval date 2 December 2021).

Informed Consent Statement: Informed consent was obtained from all subjects involved in the study.

Conflicts of Interest: The authors declare no conflict of interest.

\section{References}

1. Krakowiak, P.; Smith, E.; de Bruyn, G.; Lydon-Rochelle, M. Risk factors and outcomes associated with a short umbilical cord. Obstet. Gynecol. 2004, 103, 119-127. [CrossRef] [PubMed]

2. Sadler, T. Langman Embriologie Medicală, 10th ed.; Editura Medicală Callisto: București, Romania, 2007; pp. 79-81; 101-110.

3. Rădoi, V.; Ursu, R.; Poenaru, E.; Arsene, C.; Bohîlțea, L.; Bohîlțea, R. Frequency of the UGT1A1*28 polymorphism in a Romanian cohort of Gilbert syndrome individuals. J. Gastrointest. Liver Dis. 2017, 26, 25-28.

4. Hammad, I.A.; Blue, N.R.; Allshouse, A.A.; Silver, R.M.; Gibbins, K.J.; Page, J.M.; Goldenberg, R.L.; Reddy, U.M.; Saade, G.R.; Dudley, D.J.; et al. Umbilical Cord Abnormalities and Stillbirth. Obstet. Gynecol. 2020, 135, 644-652. [CrossRef]

5. Salomon, L.J.; Alfirevic, Z.; Bilardo, C.M.; Chalouhi, G.E.; Ghi, T.; Kagan, K.O.; Lau, T.K.; Papageorghiou, A.T.; Raine-Fenning, N.J.; Stirnemann, J.; et al. ISUOG Practice Guidelines: Performance of first-trimester fetal ultrasound scan. Ultrasound Obstet. Gynecol. 2013, 41, 102-113.

6. Salomon, L.J.; Alfirevic, Z.; Berghella, V.; Bilardo, C.; Hernandez-Andrade, E.; Johnsen, S.L.; Kalache, K.; Leung, K.Y.; Malinger, G.; Munoz, H.; et al. Practice guidelines for performance of the routine mid-trimester fetal ultrasound scan. Ultrasound Obstet. Gynecol. 2011, 37, 116-126. [CrossRef] [PubMed]

7. Salomon, L.J.; Alfirevic, Z.; da Silva Costa, F.; Deter, R.L.; Figueras, F.; Ghi, T.; Glanc, P.; Khalil, A.; Lee, W.; Napolitano, R.; et al. ISUOG Practice Guidelines: Ultrasound assessment of fetal biometry and growth. Ultrasound Obstet. Gynecol. $2019,53,715-723$. [CrossRef] [PubMed]

8. Carvalho, J.S.; Allan, L.D.; Chaoui, R.; Copel, J.A.; DeVore, G.R.; Hecher, K.; Lee, W.; Munoz, H.; Paladini, D.; Tutschek, B.; et al. ISUOG Practice Guidelines (updated): Sonographic screening examination of the fetal heart. Ultrasound Obstet. Gynecol. 2013, 41, 348-359. [CrossRef] [PubMed]

9. Bhide, A.; Acharya, G.; Baschat, A.; Bilardo, C.M.; Brezinka, C.; Cafici, D.; Ebbing, C.; Hernandez-Andrade, E.; Kalache, K.; Kingdom, J.; et al. ISUOG Practice Guidelines (updated): Use of Doppler velocimetry in obstetrics. Ultrasound Obstet. Gynecol. 2021, 58, 331-339. [CrossRef]

10. Khalil, A.; Sotiriadis, A.; Chaoui, R.; Costa, F.d.; D'Antonio, F.; Heath, P.T.; Jones, C.; Malinger, G.; Odibo, A.; Prefumo, F.; et al. ISUOG Practice Guidelines: Role of ultrasound in congenital infection. Ultrasound Obstet. Gynecol. 2020, 56, 128-151. [CrossRef] 
11. Lees, C.C.; Stampalija, T.; Baschat, A.A.; da Silva Costa, F.; Ferrazzi, E.; Figueras, F.; Hecher, K.; Kingdom, J.; Poon, L.C.; Salomon, L.J.; et al. ISUOG Practice Guidelines: Diagnosis and management of small-for-gestational-age fetus and fetal growth restriction. Ultrasound Obstet. Gynecol. 2020, 56, 298-312. [CrossRef]

12. Pellerito, J.; Bromley, B.; Allison, S.; Chauhan, A.; Destounis, S.; Dickman, E.; Kline-Fath, B.; Mastrobattista, J.; Neumyer, M.; Rundek, T.; et al. AIUM-ACR-ACOG-SMFM-SRU Practice Parameter for the Performance of Standard Diagnostic Obstetric Ultrasound Examinations. J. Ultrasound Med. 2018, 37, E13-E24.

13. Bethune, M.; Alibrahim, E.; Davies, B.; Yong, E. A pictorial guide for the second trimester ultrasound. Australas. J. Ultrasound Med. 2013, 16, 98-113. [CrossRef] [PubMed]

14. Pinar, H.; Carpenter, M. Placenta and umbilical cord abnormalities seen with stillbirth. Clin. Obstet. Gynecol. 2010, 53, 656-672. [CrossRef]

15. Gagnon, R. No. 231-Guidelines for the Management of Vasa Previa. J. Obstet. Gynaecol. Can. 2017, 39, e415-e421. [CrossRef] [PubMed]

16. Jauniaux, E.; Alfirevic, Z.; Bhide, A.; Burton, G.; Collins, S.; Silver, R. Royal College of Obstetricians and Gynaecologists. Vasa Praevia: Diagnosis and Management: Green-top Guideline No. 27b. BJOG 2019, 126, e49-e61. [CrossRef] [PubMed]

17. Bohîlțea, R.; Turcan, N.; Cîrstoiu, M. Prenatal ultrasound diagnosis and pregnancy outcome of umbilical cord knot—debate regarding ethical aspects of a series of cases. J. Med. Life 2016, 9, 297-301.

18. Merz, E.; Pashaj, S. Advantages of 3D ultrasound in the assessment of fetal abnormalities. J. Perinat. Med. 2017, 45, 643-650. [CrossRef] [PubMed]

19. Merz, E.; Welter, C. 2D and 3D Ultrasound in the evaluation of normal and abnormal fetal anatomy in the second and third trimesters in a level III center. Ultraschall Med. 2005, 26, 9-16. [CrossRef]

20. Merz, E.; Abramowicz, J. 3D/4D ultrasound in prenatal diagnosis: Is it time for routine use? Clin. Obstet. Gynecol. 2012, 55, 336-351. [CrossRef]

21. Gagnon, R.; Morin, L.; Bly, S.; Butt, K.; Cargil, Y.M.; Denis, N.; Hietala-Coyle, M.A.; Lim, K.I.; Ouellet, A.; Racicot, M.H.; et al SOGC Clinical Practice Guideline: Guidelines for the management of vasa previa. Int. J. Gynaecol. Obstet. 2010, 108, 85-89. [CrossRef]

22. Pretorius, D.; Chau, C.; Poeltler, D.; Mendoza, A.; Catanzarite, V.; Hollenbach, K. Placental cord insertion visualization with prenatal ultrasonography. J. Ultrasound Med. 1996, 15, 585-593. [CrossRef]

23. Kent, E.; Breathnach, F.; Gillan, J.; McAuliffe, F.; Geary, M.; Daly, S.; Higgins, J.; Dornan, J.; Morrison, J.; Burke, G.; et al. Placental cord insertion and birthweight discordance in twin pregnancies: Results of the national prospective ESPRiT Study. Am. J. Obstet. Gynecol. 2011, 205, e1-e7. [CrossRef]

24. Sepulveda, W.; Rojas, I.; Robert, J.; Schnapp, C.; Alcalde, J. Prenatal detection of velamentous insertion of the umbilical cord: A prospective color Doppler ultrasound study. Ultrasound Obstet. Gynecol. 2003, 21, 564-569. [CrossRef] [PubMed]

25. Cirstoiu, M.; Turcan, N.; Bratila, E. Velamentous cord insertion-an important obstetrical risk factor. Gineco.eu 2016, 12, 129-134.

26. Bohîlțea, R.; Cîrstoiu, M.; Ciuvica, A.; Munteanu, O.; Bodean, O.; Voicu, D.; Ionescu, C. Velamentous insertion of umbilical cord with vasa praevia: Case series and literature review. J. Med. Life 2016, 9, 126-129.

27. Ebbing, C.; Kiserud, T.; Johnsen, S.; Albrechtsen, S.; Rasmussen, S. Third stage of labor risks in velamentous and marginal cord insertion: A population-based study. Acta Obstet. Gynecol. Scand. 2015, 94, 878-883. [CrossRef]

28. Hoyme, H.; Jones, K.; van Allen, M.; Saunders, B.; Benirschke, K. Vascular pathogenesis of transverse limb reduction defects. J. Pediatr. 1982, 101, 839-843. [CrossRef]

29. Williams, J.; Benirschke, K. Chorionic vessel thrombosis: A possible etiology of neonatal purpura. J. Reprod. Med. 1978, 20, 285-288.

30. Catanzarite, V.; Maida, C.; Thomas, W.; Mendoza, A.; Stanco, L.; Piacquadio, K. Prenatal sonographic diagnosis of vasa previa: Ultrasound findings and obstetric outcome in ten cases. Ultrasound Obstet. Gynecol. 2001, 18, 109-115. [CrossRef] [PubMed]

31. Zhang, W.; Geris, S.; Beta, J.; Ramadan, G.; Nicolaides, K.; Akolekar, R. Prevention of stillbirth: Impact of two-stage screening for vasa previa. Ultrasound Obstet. Gynecol. 2020, 55, 605-612. [CrossRef] [PubMed]

32. Dudiak, C.; Salomon, C.; Posniak, H.; Olson, M.; Flisak, M. Sonography of the umbilical cord. Radiographics 1995, 15, 1035-1050. [CrossRef] [PubMed]

33. Nkwabong, E.; Njikam, F.; Kalla, G. Outcome of pregnancies with marginal umbilical cord insertion. J. Matern. Fetal Neonatal Med. 2021, 34, 1133-1137. [CrossRef] [PubMed]

34. Van Zalen-Sprock, R.; Vugt, J.; van Geijn, H. First-trimester sonography of physiological midgut herniation and early diagnosis of omphalocele. Prenat. Diagn. 1997, 17, 511-518. [CrossRef]

35. Liang, Y.-L.; Kang, L.; Tsai, P.-Y.; Cheng, Y.-C.; Ko, H.-C.; Chang, C.-H.; Chang, F.-M. Prenatal diagnosis of fetal omphalocele by ultrasound: A comparison of two centuries. Taiwan. J. Obstet. Gynecol. 2013, 52, 258-263. [CrossRef] [PubMed]

36. Robinson, B.; Grobman, W. Effectiveness of timing strategies for delivery of individuals with vasa previa. Obstet. Gynecol. 2011, 117, 542-549. [CrossRef]

37. Sermer, M.; Benzie, R.; Pitson, L.; Carr, M.; Skidmore, M. Prenatal diagnosis and management of congenital defects of the anterior abdominal wall. Am. J. Obstet. Gynecol. 1987, 156, 308-312. [CrossRef]

38. Nyberg, D.; Fitzsimmons, J.; Mack, L.; Hughes, M.; Pretorius, D.; Hickok, D.; Shepard, T. Chromosomal abnormalities in fetuses with omphalocele. Significance of omphalocele contents. J. Ultrasound Med. 1989, 8, 299-308. [CrossRef] 
39. Benacerraf, B.; Saltzman, D.; Estroff, J.; Frigoletto, F.J. Abnormal karyotype of fetuses with omphalocele: Prediction based on omphalocele contents. Obstet. Gynecol. 1990, 75 Pt 1, 317-319. [PubMed]

40. Morrow, R.; Whittle, M.; McNay, M.; Raine, P.; Gibson, A.; Crossley, J. Prenatal diagnosis and management of anterior abdominal wall defects in the west of Scotland. Prenat. Diagn. 1993, 13, 111-115. [CrossRef]

41. Rossi, A.; Prefumo, F. Impact of cord entanglement on perinatal outcome of monoamniotic twins: A systematic review of the literature. Ultrasound Obstet. Gynecol. 2013, 41, 131-135. [CrossRef]

42. Larson, J.; Rayburn, W.; Harlan, V. Nuchal cord entanglements and gestational age. Am. J. Perinatol. 1997, 14, 555-557. [CrossRef]

43. Miser, W. Outcome of infants born with nuchal cords. J. Fam. Pract. 1992, 34, 441-445. [CrossRef] [PubMed]

44. Schreiber, H.; Daykan, Y.; Arbib, N.; Markovitch, O.; Berkovitz, A.; Biron-Shental, T. Adverse pregnancy outcomes and multiple nuchal cord loops. Arch. Gynecol. Obstet. 2019, 300, 279-283. [CrossRef]

45. Mariya, T.; Fujibe, Y.; Shinkai, S.; Sugita, N.; Suzuki, M.; Endo, T.; Saito, T. Multiple part umbilical cord entanglement and neonatal outcomes. Taiwan J. Obstet. Gynecol. 2018, 57, 672-676. [CrossRef]

46. Sepulveda, W. Antenatal course and perinatal outcome after ultrasound detection of triple nuchal cord: A case series. J. Matern. Fetal Neonatal Med. 2021, 34, 3246-3251. [CrossRef] [PubMed]

47. Schäffer, L.; Burkhardt, T.; Zimmermann, R.; Kurmanavicius, J. Nuchal cords in term and postterm deliveries-do we need to know? Obstet. Gynecol. 2005, 106, 23-28. [CrossRef] [PubMed]

48. Gore, R.; Filly, R.; Parer, J. Sonographic antepartum diagnosis of conjoined twins. Its impact on obstetric management. JAMA 1982, 247, 3351-3353. [CrossRef]

49. Hayes, D.; Warland, J.; Parast, M.; Bendon, R.; Hasegawa, J.; Banks, J.; Clapham, L.; Heazell, A. Umbilical cord characteristics and their association with adverse pregnancy outcomes: A systematic review and meta-analysis. PLoS ONE 2020, 15, e0239630.

50. Peregrine, E.; O'Brien, P.; Jauniaux, E. Ultrasound detection of nuchal cord prior to labor induction and the risk of caesarean section. Ultrasound Obstet. Gynecol. 2005, 25, 160-164. [CrossRef] [PubMed]

51. Rembouskos, G.; Cicero, S.; Longo, D.; Sacchini, C.; Nicolaides, K. Single umbilical artery at 11-14 weeks' gestation: Relation to chromosomal defects. Ultrasound Obstet. Gynecol. 2003, 22, 567-570. [CrossRef]

52. Thummala, M.; Raju, T.; Langenberg, P. Isolated single umbilical artery anomaly and the risk for congenital malformations: A meta-analysis. J. Pediatr. Surg. 1998, 33, 580-585. [CrossRef]

53. Abuhamad, A.; Shaffer, W.; Mari, G.; Copel, J.; Hobbins, J.; Evans, A. Single umbilical artery: Does it matter which artery is missing? Am. J. Obstet. Gynecol. 1995, 173 Pt 1, 728-732. [CrossRef]

54. Leung, A.; Robson, W. Single umbilical artery. A report of 159 cases. Am. J. Dis. Child. 1989, 143, 108-111. [CrossRef] [PubMed]

55. Gornall, A.; Kurinczuk, J.; Konje, J. Antenatal detection of a single umbilical artery: Does it matter? Prenat. Diagn. 2003, 23, 117-123. [CrossRef]

56. Burshtein, S.; Levy, A.; Holcberg, G.; Zlotnik, A.; Sheiner, E. Is single umbilical artery an independent risk factor for perinatal mortality? Arch. Gynecol. Obstet. 2011, 283, 191-194. [CrossRef] [PubMed]

57. Nastas, A.; Stanculescu, R.; Mehedințu, C.; Berceanu, C.; Comandasu, D.; Cîrstoiu, M.; Bohîlțea, R.; Vladareanu, S.; Patrascoiu, S.; Nastas, A.; et al. The Management of Grade II/III Hydronephrosis during Pregnancy. In Proceedings of the 13th National Congress of Urogynecology, Brasov, Romania, 29 September-1 October 2016; Filodiritto Editore: Bologna, Italy.

58. Petrikovsky, B.; Schneider, E. Prenatal diagnosis and clinical significance of hypoplastic umbilical artery. Prenat. Diagn. 1996, 16, 938-940. [CrossRef]

59. Pérez-Cosio, C.; Sheiner, E.; Abramowicz, J. Four-vessel umbilical cord: Not always a dire prognosis. J. Ultrasound Med. 2008, 27, 1389-1391. [CrossRef] [PubMed]

60. Cohen, H.; Shapiro, M.; Haller, J.; Schwartz, D. The multivessel umbilical cord: An antenatal indicator of possible conjoined twinning. J. Clin. Ultrasound 1992, 20, 278-282. [CrossRef] [PubMed]

61. Lei, T.; Xie, H.; Feng, J. Prenatal diagnosis of four-vessel umbilical cord with supernumerary vein varix: A case report and literature review. J. Obstet. Gynaecol. Res. 2017, 43, 1200-1204. [CrossRef] [PubMed]

62. Krzyżanowski, A.; Swatowski, D.; Gęca, T.; Kwiatek, M.; Stupak, A.; Woźniak, S.; Kwaśniewska, A. Prenatal diagnosis of persistent right umbilical vein-Incidence and clinical impact. A prospective study. Aust. N. Z. J. Obstet. Gynaecol. 2019, 59, 77-81. [CrossRef]

63. McCalla, C.; Lajinian, S.; DeSouza, D.; Rottem, S. Natural history of antenatal omphalomesenteric duct cyst. J. Ultrasound Med. 1995, 14, 639-640. [CrossRef]

64. Marsál, K. Intrauterine growth restriction. Curr. Opin. Obstet. Gynecol. 2002, 14, 127-135. [CrossRef]

65. Sánchez-Códez, M.; Lubián-Gutiérrez, M.; Méndez-Abad, P. Umbilical Cord Hematoma. Fetal Pediatr. Pathol. 2019, 38, 359-360. [CrossRef]

66. Byers, B.; Goharkhay, N.; Mateus, J.; Ward, K.; Munn, M.; Wen, T. Pregnancy outcome after ultrasound diagnosis of fetal intra-abdominal umbilical vein varix. Ultrasound Obstet. Gynecol. 2009, 33, 282-286. [CrossRef]

67. Lee, S.; Kim, M.; Kim, J.; Chung, J.; Lee, H.; Yoon, J. Clinical characteristics and outcomes of antenatal fetal intra-abdominal umbilical vein varix detection. Obstet. Gynecol. Sci. 2014, 57, 181-186. [CrossRef]

68. Ross, J.; Jurkovic, D.; Zosmer, N.; Jauniaux, E.; Hacket, E.; Nicolaides, K. Umbilical cord cysts in early pregnancy. Obstet. Gynecol. 1997, 89, 442-445. [CrossRef] 
69. Ahmed, N.; Kale, V.; Thakkar, H.; Hanchate, V.; Dhargalkar, P. Sonographic diagnosis of placental teratoma. J. Clin. Ultrasound 2004, 32, 98-101. [CrossRef] [PubMed]

70. Diwakar, R.; Naik, M.; Jindal, M. Umbilical cord coiling: Case report and review of literature. BJR Case Rep. $2017,2,20150152$. [CrossRef] [PubMed]

71. Sepulveda, W.; Wong, A.; Gomez, L.; Alcalde, J. Improving sonographic evaluation of the umbilical cord at the second-trimester anatomy scan. J. Ultrasound Med. 2009, 28, 831-835. [CrossRef]

72. Stefos, T.; Sotiriadis, A.; Vasilios, D.; Tsirkas, P.; Korkontzelos, I.; Avgoustatos, F.; Lolis, D. Umbilical cord length and parity-the Greek experience. Eur. J. Obstet. Gynecol. Reprod. Biol. 2003, 107, 41-44. [CrossRef]

73. Suzuki, S. Excessively long umbilical cord: A preventive factor of miserable outcomes of pregnancies with true umbilical cord knots. J. Matern. Fetal Neonatal Med. 2019, 33, 3757-3760. [CrossRef]

74. Ruiter, L.; Kok, N.; Limpens, J.; Derks, J.; de Graaf, I.; Mol, B.; Pajkrt, E. Incidence of and risk indicators for vasa praevia: A systematic review. BJOG 2016, 123, 1278-1287. [CrossRef]

75. Francois, K.; Mayer, S.; Harris, C.; Perlow, J. Association of vasa previa at delivery with a history of second-trimester placenta previa. J. Reprod. Med. 2003, 48, 771-774. [CrossRef]

76. Suekane, T.; Tachibana, D.; Pooh, R.; Misugi, T.; Koyama, M. Type-3 vasa previa: Normal umbilical cord insertion cannot exclude vasa previa in cases with abnormal placental location. Ultrasound Obstet. Gynecol. 2020, 55, 556-557. [CrossRef]

77. Luo, G.; Redline, R. Peripheral insertion of umbilical cord. Pediatr. Dev. Pathol. 2013, 16, 399-404. [CrossRef]

78. Ismail, K.; Hannigan, A.; O'Donoghue, K.; Cotter, A. Abnormal placental cord insertion and adverse pregnancy outcomes: A systematic review and meta-analysis. Syst. Rev. 2017, 6, 242. [CrossRef] [PubMed]

79. Sun, J.; Wang, L.; Li, Y. Clinical value of color doppler ultrasound in prenatal diagnosis of umbilical cord entry abnormity. Pak. J. Med. Sci. 2016, 32, 1414-1418. [CrossRef]

80. Waller, D.; Shaw, G.; Rasmussen, S.; Hobbs, C.; Canfield, M.; Siega-Riz, A.; Gallaway, M.; Correa, A. Prepregnancy Obesity as a Risk Factor for Structural Birth Defects. Arch. Pediatr. Adolesc. Med. 2007, 161, 745-750. [CrossRef]

81. Blackburn, W.; Cooley, W. Umbilical cord. In Human Malformations and Related Anomalies, 2nd ed.; Oxford University Press: New York, NY, USA, 1993; p. 1275.

82. Proctor, L.; Fitzgerald, B.; Whittle, W.; Mokhtari, N.; Lee, E.; Machin, G.; Kingdom, J.; Keating, S. Umbilical cord diameter percentile curves and their correlation to birth weight and placental pathology. Placenta 2013, 34, 62-66. [CrossRef] [PubMed]

83. Catanzarite, V.; Hendricks, S.; Maida, C.; Westbrook, C.; Cousins, L.; Schrimmer, D. Prenatal diagnosis of the two-vessel cord: Implications for patient counselling and obstetric management. Ultrasound Obstet. Gynecol. 1995, 5, 98-105. [CrossRef] [PubMed]

84. Sepulveda, W.; Flack, N.; Bower, S.; Fisk, N. The value of color Doppler ultrasound in the prenatal diagnosis of hypoplastic umbilical artery. Ultrasound Obstet. Gynecol. 1994, 4, 143-146. [CrossRef]

85. Hua, M.; Odibo, A.; Macones, G.; Roehl, K.; Crane, J.; Cahill, A. Single umbilical artery and its associated findings. Obstet. Gynecol. 2010, 115, 930-934. [CrossRef]

86. Dagklis, T.; Defigueiredo, D.; Staboulidou, I.; Casagrandi, D.; Nicolaides, K. Isolated single umbilical artery and fetal karyotype Ultrasound Obstet. Gynecol. 2010, 36, 291-295. [CrossRef]

87. Van den Hof, M.; Wilson, R. Fetal soft markers in obstetric ultrasound. J. Obstet. Gynaecol. Can. 2005, 27, 592-636. [PubMed]

88. Cajal, C.R.Y.; Martínez, R. Prenatal diagnosis of true knot of the umbilical cord. Ultrasound Obstet. Gynecol. 2004, 223, 99-100. [CrossRef] [PubMed]

89. Abuhamad, A. Three-dimensional ultrasound with color Doppler imaging of an umbilical cord true knot. Ultrasound Obstet. Gynecol. 2014, 43, 360. [CrossRef] [PubMed]

90. Collins, J. Nuchal cord type A and type B. Am. J. Obstet. Gynecol. 1997, 177, 94. [CrossRef]

91. Zahoor, F.; Minhas, Z.; Zaki, A. Perinatal Outcome of Nuchal Cord. J. Postgrad. Med. Inst. 2013, 5, 360-363.

92. Sherer, D.; Roach, C.; Soyemi, S.; Dalloul, M. Current Perspectives of Prenatal Sonographic Diagnosis and Clinical Management Challenges of Complex Umbilical Cord Entanglement. Int. J. Womens Health 2021, 13, 247-256. [CrossRef]

93. Ranzini, A.; Walters, C.; Vintzileos, A. Ultrasound diagnosis of nuchal cord: The gray-scale divot sign. Obstet. Gynecol. 1999, 93 Pt 2, 854. [CrossRef]

94. Chew, M.; Teoh, P.; Wong, Y.; Tan, G. Multiple umbilical cord strictures in a case of intrauterine foetal demise. Malays. J. Pathol. 2019, 41, 365-368. [PubMed]

95. French, A.; Gregg, V.; Newberry, Y.; Parsons, T. Umbilical cord stricture: A cause of recurrent fetal death. Obstet. Gynecol. 2005, 105 Pt 2, 1235-1239. [CrossRef]

96. Sepulveda, W.; Shennan, A.; Bower, S.; Fisk, N. Discordant umbilical artery flow velocity waveforms in spontaneous umbilical cord hematoma. J. Clin. Ultrasound 1995, 23, 330-332. [CrossRef]

97. Sepulveda, W.; Mackenna, A.; Sanchez, J.; Corral, E.; Carstens, E. Fetal prognosis in varix of the intrafetal umbilical vein. J. Ultrasound Med. 1998, 17, 171-175. [CrossRef]

98. Novoa, V.; Shazly, S.; Ibirogba, E.R.; Sutton, L.; Tonni, G.; Prefumo, F.; Sepulveda, W.; Júnior, E.A.; Werner, H.; Trinidad, M.C.; et al. Perinatal outcomes of fetal intra-abdominal umbilical vein varix: A multicenter cohort study. J. Matern. Fetal Neonatal Med. 2021, 34, 3393-3396. [CrossRef]

99. Sepulveda, W.; Corral, E.; Kottmann, C.; Illanes, S.; Vasquez, P.; Monckeberg, M. Umbilical artery aneurysm: Prenatal identification in three fetuses with trisomy 18. Ultrasound Obstet. Gynecol. 2003, 21, 292-296. [CrossRef] 
100. Persutte, W.; Lenke, R.; Kropp, K.; Ghareeb, C. Antenatal diagnosis of fetal patent urachus. J. Ultrasound Med. 1988, 7, 399-403. [CrossRef]

101. Smith, G.; Walker, M.; Johnston, S.; Ash, K. The sonographic finding of persistent umbilical cord cystic masses is associated with lethal aneuploidy and/or congenital anomalies. Prenat. Diagn. 1996, 16, 1141-1147. [CrossRef]

102. Hill, L. The sonographic detection of trisomies 13, 18, and 21. Clin. Obstet. Gynecol. 1996, 39, 831-850. [CrossRef]

103. Hargitai, B.; Csabai, L.; Bán, Z.; Hetényi, I.; Szucs, I.; Varga, S.; Papp, Z. Rare case of exomphalos complicated with umbilical cord teratoma in a fetus with trisomy 13. Fetal Diagn. Ther. 2005, 20, 528-533. [CrossRef] [PubMed]

104. El-Messidi, A.; Fung, K. Umbilical cord hernia mimicking a cord teratoma. J. Obstet. Gynaecol. Can. 2009, 31, 533-537. [CrossRef]

105. Satgé, D.; Laumond, M.; Desfarges, F.; Chenard, M. An umbilical cord teratoma in a 17-week-old fetus. Prenat. Diagn. 2001, 21, 284-288. [CrossRef] [PubMed]

106. Ghidini, A.; Romero, R.; Eisen, R.; Smith, G.; Hobbins, J. Umbilical cord hemangioma. Prenatal identification and review of the literature. J. Ultrasound Med. 1990, 9, 297-300. [CrossRef] [PubMed]

107. Jauniaux, E.; Moscoso, G.; Chitty, L.; Gibb, D.; Driver, M.; Campbell, S. An angiomyxoma involving the whole length of the umbilical cord. Prenatal diagnosis by ultrasonography. J. Ultrasound Med. 1990, 9, 419-422. [CrossRef]

108. De Laat, M.; Franx, A.; Bots, M.; Visser, G.; Nikkels, P. Umbilical coiling index in normal and complicated pregnancies. Obstet. Gynecol. 2006, 107, 1049-1055. [CrossRef]

109. AIUM Practice Parameter for the Performance of Detailed Second- and Third-Trimester Diagnostic Obstetric Ultrasound Examinations. Ultrasound Med. 2019, 38, 3093-3100. [CrossRef]

110. Sepulveda, W. Prenatal Diagnosis and Management of Umbilical Cord Abnormalities. 2017. Available online: https://www. uptodate.com/contents/umbilical-cord-abnormalities-prenatal-diagnosis-and-management (accessed on 4 January 2022). 